\title{
Tbet expression by Tregs is needed to protect against Th1-mediated immunopathology during Toxoplasma infection in mice
}

Jordan Warunek $^{*}$, Richard M. Jin*, Sarah J. Blair ${ }^{*}$, Matthew Garis*, Brandon Marzullo ${ }^{\ddagger}$ and Elizabeth A. Wohlfert*

*Department of Microbiology and Immunology, Jacobs School of Medicine and Biomedical

Sciences, State University of New York at Buffalo, Amherst, NY, 14260 and ${ }^{\dagger}$ Genomics and Bioinformatics Core, State University of New York at Buffalo, Amherst, NY 14260

Corresponding Author: Elizabeth A. Wohlfert

Phone: 716-829-3969

Fax: 716-829-2158

Email: $\underline{\text { wohlfert@,buffalo.edu }}$

Keywords: T. gondii, Tregs, Tbet, immunopathology 


\section{Abstract}

T. gondii infection has proven to be an ideal model to understand the delicate balance between protective immunity and immune-mediated pathology during infection. Lethal infection causes a collapse of Tregs mediated by loss of IL-2, and conversion of Tregs to IFN $\gamma$ producing cells. Importantly, these Tregs highly express the Th1 transcription factor Tbet. To determine the role of Tbet in Tregs, we infected Tbx $21^{f f f}$-Foxp $3^{\text {YFPCre }}$ and control Foxp $3^{\text {YFPCre }}$ mice with the type II strain of T. gondii, ME49. The majority of $T b \times 21^{f f f}$-Foxp $3^{\text {YFPCre }}$ mice succumb to a non-lethal acute infection. Notably, parasite burden is comparable between $T b \times 21^{f / f}$-Foxp3 ${ }^{\text {YFPCre }}$ and Foxp $3^{\text {YFPCre }}$ control mice. We found that $T b x 21^{f f}-$ Foxp $3^{\text {YFPCre }}$ mice have significantly higher serum levels of proinflammatory cytokines IFN $\gamma$ and $\mathrm{TNF} \alpha$, suggestive of a heightened immune response. To test if $\mathrm{CD}^{+} \mathrm{T}$ cells were driving immunopathology, we treated $T b x 2^{f f f}$-Foxp $3^{\mathrm{YFPCre}}$ mice with anti-CD4 depleting antibody and partially rescued these mice. Broad spectrum antibiotic treatment also improved survival, demonstrating a role for commensal flora in immunopathology in $T b x 21^{f f f}-$ Foxp $3^{\text {YFPCre }}$ mice. RNA-seq analysis reinforced that Tbet regulates several key cellular pathways, including chromosome segregation, cytokine receptor activity and cell cycle progression, that help to maintain fitness in Tregs during Th1 responses. Taken together, our data shows an important role for Tbet in Tregs in preventing lethal immunopathology during Toxoplasma gondii infection, further highlighting the protective role of Treg plasticity to self and microbiota. 


\section{Introduction}

The sustained presence of regulatory $\mathrm{T}$ cells (Tregs) is vital to maintaining immunologic homeostasis and required for host survival as evidenced by the emergence of autoimmune diseases when Treg suppressive function is disrupted $(1,2)$. Tregs not only regulate autoimmune responses but they also modulate immune responses to invading pathogens and defective Treg functionality has been implicated in a spectrum of pathologies $(1,3)$. As the immunological landscape rapidly changes during an infection, Tregs must adapt to the inflammatory environment. This adaptation, termed Treg plasticity, endows them with certain features of $\mathrm{T}$ helper cells that enhance survival and functionality of Tregs in diverse inflammatory conditions (4-11). For example, the acquisition of certain Th1 effector properties aids in enhancing suppression during Th1 inflammation and the upregulation of CXCR3 confers precise homing and accumulation at these sites, however not all of the acquired phenotypes are fully understood (12-15). Tregs in $\mathrm{T}$ helper 1 cells (Th1) polarized inflammatory environments will also upregulate Tbet, the lineage-specifying transcription factor for Th1 cells (4-11). During both acute and chronic T. gondii infection in mice, Tbet-expressing Tregs can be found throughout the host $(12,16-20)$, including the small intestinal lamina propria, brain, muscle, spleen and lymph nodes $(11,12,16-20)$. Notably, Tregs in skeletal muscle express equivalent levels of Tbet compared to $\mathrm{CD}^{+}$effector $\mathrm{T}$ cells (16). Yet, its functional role in Tregs during T. gondii infections had not been explored.

Th1-like Tregs ( Tbet $^{+}$Tregs) are a highly stable population of Tregs, suggesting their persistence is advantageous to the host if they possess a suppressive function and their specificity 
is towards self-antigen (14). Our lab has previously shown that, during chronic T. gondii infections, Th1-like Tregs are perpetrators of muscle damage by promoting macrophages to maintain proinflammatory M1 properties instead of tissue regenerative M2 phenotypes (16). These disparate findings in immunoregulatory processes led us to question whether Tbet expression in Tregs was essential for host response and control of T. gondii. This is important because there is also debate on the role of Tbet in Tregs within the inflamed gastrointestinal tract and if Tbet is needed for Treg function $(21,13,22)$. Taken together, these ambiguities led us to question whether Tbet expression in Tregs is required for host response and control of T. gondii infection.

To address this question, we infected Treg-specific Tbet deficient conditional mice, Tbx2 $1^{f f f}-$ Foxp $3^{\text {YFPCre }}$, and control Foxp $3^{\text {YFPCre }}$ mice with the type II strain ME49. In our attempt to understand if Tbet was driving the pathology in chronically infected muscle, we discovered that Tbet is required for survival of the host during acute infection. Interestingly, while Tbet expression by Tregs was required for survival of acutely infected mice, it did not influence host control of the parasite. We found that both $\mathrm{CD}^{+} \mathrm{T}$ cells and the commensal flora partially drove the immunopathology observed in the $T b x 21^{f f f}-$ Foxp $3^{\text {YFPCre }}$ mice during acute infection with $T$. gondii. RNA sequencing on sorted splenic Tregs from day 10 infected $T b x 21^{f f f}$-Foxp $3^{\text {YFPCre }}$ and Foxp $3^{\text {YFPCre }}$ mice highlighted several cellular pathways regulated by Tbx21 in Th1-Tregs. Among these include pathways related to chromosome segregation, cytokine receptor activity and cell cycle progression. Taken together this reveals a critical role for Tbet in mediating the fitness of 
bioRxiv preprint doi: https://doi.org/10.1101/2021.09.03.458860; this version posted September 4, 2021. The copyright holder for this preprint (which was not certified by peer review) is the author/funder, who has granted bioRxiv a license to display the preprint in perpetuity. It is made available under aCC-BY-NC-ND 4.0 International license.

the Treg response to infection induced dysbiosis, and remains a vital determinant of host survival during oral T. gondii infection. 


\section{Materials and Methods}

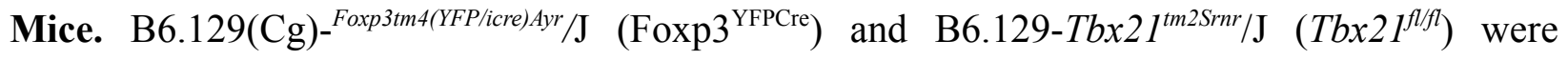
purchased from Jackson Laboratories (Bar Harbor, ME) and crossed to generate Tbx2 $1^{f f f}$-Foxp $3^{\text {YFPCre }}$ mice. All experimental mice were raised in SPF conditions and were sex and age matched and used at 8 to 10 weeks old at the time of infection. Both males and females were used in experiments. All procedures involving mice were reviewed and approved by the Institutional Animal Care and Use Committee at the University at Buffalo.

Isolation of tissue lymphocytes from organs. Spleen and mesenteric lymphocytes were harvested by passing through Falcon $70 \mu \mathrm{m}$ cell strainers to create single suspensions in $2 \%$ media (RPMI with $2 \% \quad$ FBS, $25 \quad \mathrm{mM} \quad$ HEPES, $0.1 \% \quad \beta$-mercaptoethanol, $1 \%$ penicillin-streptomycin, 1\% L-Glutamine). Red blood cells were lysed as needed on ice for 3 minutes and resuspended in 10\% media (RPMI with 10\% FBS, $25 \mathrm{mM}$ HEPES, 0.1\% $\beta$-mercaptoethanol, 1\% penicillin-streptomycin, 1\% L-Glutamine).

Liver was collected and finely minced in digestion media (RPMI, 1\% penicillin-streptomycin, $1 \mathrm{mM}$ sodium pyruvate, $0.1 \% \quad \beta$-mercaptoethanol, $25 \mathrm{mM}$ HEPES, $150 \mu \mathrm{g} / \mathrm{ml}$ DNase I [Sigma-Aldrich], 0.5mg/ml Liberase [Roche] and then slow spun at 50xg for 5 mins (11). Small intestinal lamina propria (SILp) were isolated as previously described (11). SILp was harvested, cut into $0.5 \mathrm{~cm}$ pieces and pre-digested in $3 \%$ Media with $5 \mathrm{mM}$ EDTA and $0.145 \mathrm{mg} / \mathrm{mL}$ DTT for 20 minutes at $37^{\circ} \mathrm{C}$. The lamina propria was isolated from flow through epithelium by shaking in $2 \mathrm{mM}$ EDTA, 25mM Hepes, and 1\% penicillin-streptomycin media. The tissue was then finely minced in digestion media containing Liberase and DNase I and incubated for 30 
minutes at $37^{\circ} \mathrm{C}$ degrees (11). Digested tissue was passed through a $70 \mu \mathrm{M}$ and then $40 \mu \mathrm{M}$ strainer. SILP single cell suspensions were resuspended in 10\% media (RPMI with 10\% FBS, $1 \%$ penicillin-streptomycin, $1 \mathrm{mM}$ sodium pyruvate, $0.1 \% \beta$-mercaptoethanol, $25 \mathrm{mM}$ HEPES).

Extracellular and Intracellular flow cytometric analysis of tissue lymphocytes. Single-cell suspensions were stained with HBSS containing extracellular surface antibodies and Live/Dead Fixable Blue Dead Cell Stain (Life Technologies). After extracellular staining for 25 minutes on ice, cells were fixed and permeabilized overnight (Intracellular Fixation and Permeabilization Buffer Set, Thermo Fisher eBioscience). Cells were then washed and stained with the eBioscience Permeabilization Buffer containing intracellular antibodies for 45 minutes on ice. Samples were washed and resuspended in flow cytometry buffer/FACS Buffer (PBS, 1\% bovine serum albumin [Sigma-Aldrich], 2mM EDTA [Life Technologies]) for acquisition on a BD Fortessa SORP. Absolute numbers were derived from cell counts using a hemocytometer (Life Technologies) or CountBright Absolute Counting Beads (Invitrogen).

T. gondii-specific tetramer staining. Single-cell suspensions of tissue lymphocytes were stained with allophycocyanin-conjugated MHC class II tetramers bound to T. gondii ME49 hypothetical antigenic peptide I-A(b) (AVEIHRPVPGTAPPS) obtained through the National Institute of Health Tetramer Facility (Atlanta, GA). Cells were incubated with the $T$. gondii-specific tetramer or CLIP tetramer for 1 hour at room temperature. After $T$. gondii-specific staining, cells were stained with extracellular and intracellular antibodies as described previously. 
Antibodies. Antibodies used in flow cytometric analysis were: anti-TCR $\beta$-APC-Cy7 (BD Pharmigen, clone H57-597), anti-CD4-PE-Cy7 (BD Pharmigen, clone RM4-5), anti-CD4-V450 (clone RM4-5, BD Pharmingen), anti-CD8b-Percp-Cy5.5 (clone H35-17.2, BD Pharmingen), anti-CD11a-BV650 (clone 2D7, BD Pharmingen), anti-CD49D-BV421 (clone R1-2, BD Pharmingen), anti-Foxp3-FITC (eBioscience, clone FJK-16s), anti-Tbet-PE (eBioscience, clone eBio4B10), anti-Ki67-AF700 (BD Pharmingen, clone B56). Flow cytometry data was acquired using a BD LSRFortessa Cell Analyzer and analyzed using FlowJo version 10.0.8 (Tree Star, Ashland, OR).

Detection of serum cytokines. Sera was isolated from mice either by cardiac puncture or collected by submandibular vein puncture at various time points. Assessment of the sera cytokines was performed by ELISA to detect IFN $\gamma$ and TNF $\alpha$ (eBioscience) at 10 to 12 days post-infection.

Toxoplasma infection. Brains were isolated from chronic T. gondii infected mice (30 to 60 days post-infection). The brain was homogenized in phosphate-buffered saline $\mathrm{pH} 7.2$ (PBS) for oral infection (12). RFP-expressing ME49 cysts from brain homogenates were enumerated using a fluorescence microscope to detect RFP and counted in triplicate. Mice were orally gavaged with five ME49 ${ }^{\text {RFP }}$ cysts in 200ul PBS. Mouse weight, activity and posture were scored every other day for the first 8 days of infection, monitored daily during acute infection at day 8 through day 14 and then weekly thereafter.

Antibody depletion of $\mathbf{C D}^{+} \mathbf{T}$ cells in vivo. Groups of $T b x 21^{f f f}$-Foxp $3^{\mathrm{YFPCre}}$ and Foxp $3^{\mathrm{YFPCre}}$ mice were treated with either $0.5 \mathrm{mg}$ of anti-mouse CD4, (clone GK1.5), or rat IgG2b isotype control 
anti-keyhole limpet hemocyanin, (clone LTF-2) (Bio X Cell's InVivoMab). Mice were intraperitoneally injected with a depleting antibody or isotype control on days $-5,-1,0$ pre-infection and on days 5, 14, 19 post-infection.

Antibiotic Treatment. To deplete gut microbiota, groups of Foxp3 $3^{\mathrm{YFPCre}}$ and $T b x 2^{f_{f f}}$-Foxp $3^{\mathrm{YFPCre}}$ mice were given broad-spectrum antibiotics in their drinking water (23). The following antibiotics were added to autoclaved tap water: ampicillin $(1 \mathrm{~g} / \mathrm{L})$, vancomycin $(500 \mathrm{mg} / \mathrm{L})$, neomycin sulfate (1 g/L), and metronidazole (1 g/L) (Sigma-aldrich, St. Louis, MO) and administered ad libitum using drinking bottles. A set of mice from each group were designated as untreated controls and received water supplied from the animal facility. Antibiotic treatment started two weeks prior to infection with $T$. gondii and was administered until three weeks post-infection, a total of five weeks of treatment.

Analysis of bacterial $16 \mathrm{~S}$ genes. Feces were collected prior to antibiotic water administration and at various time points thereafter. Fecal pellets were collected directly into microcentrifuge tubes and immediately placed on dry ice until storage in a -80 freezer. Bacterial DNA was isolated using the QIAamp Fast DNA Stool Mini Kit (Qiagen). Quantification of DNA was done using a nanodrop. qPCR was performed using the iTaq Universal SYBR Green Mastermix (BioRad) on a StepOne ${ }^{\mathrm{TM}}$ Real-Time PCR System. Bacterial detection was analyzed using amplification of the 16 s ribosomal subunit of specific populations. The selected bacteria to be analyzed by qPCR were Eubacteria, Enterobacteriaceae, Escherichia coli, Bacteroides, Eubacterium rectale/Clostridium coccoides group (EREC) (24). Primer sequences are included in Table 1. 
Quantification of parasite burden. Mouse organ tissues were harvested and preserved in RNAlater (Invitrogen) for DNA isolation using a DNeasy Blood \& Tissue Kit (Qiagen). DNA was quantified using a Nanodrop Spectrophotometer for quality and concentration. An amount of 200ng of various tissue DNA was used in PCR amplification of the $T$. gondii specific repetitive gene B1 (forward: 5'-TCCCCTCTGCTGGCGAAAAGT-3', reverse: 5'-AGCGTTCGTGGTCAACTATCGATTG-3'). Parasite burden was calculated using a comparison of a standard curve of known $T$. gondii genomic DNA amplified with $B 1$ specific primers.

Blood chemistry assays and complete blood count. Blood was collected by cardiac puncture after euthanasia from T. gondii infected mice. For chemistry analysis, the blood was placed in tubes without anticoagulants and placed on ice until analysis. UB LAF veterinary staff analyzed blood chemistry using an Element DC Veterinary Chemistry Analyzer (Heska). For complete blood counts, blood was placed on ice in tubes coated with EDTA and analyzed using an Element HT5 Veterinary Hematology Analyzer (Heska).

RNA-Seq. Tregs were sort purified from $T b x 2^{f f f}$-Foxp $3^{\text {YFPCre }}$ and Foxp $3^{\text {YFPCre }}$ mice 9 days after being infected with five ME49 cysts. Total RNA to be sequenced was extracted from $1 \times 10^{6}$ sort purified Tregs using TRIzol (Thermo Fisher). RNA sequencing was performed and analyzed at the UB Genomics and Bioinformatics Core Facility using the R package DESeq2 to determine differentially expressed genes between Tregs from infected $T b x 21^{f f f}-$ Foxp $3^{\text {YFPCre }}$ and Foxp $3^{\text {YFPCre }}$. Gene ontology analysis was performed using the GOseq Bioconductor package version 1.42.0. GOseq performs Gene Ontology analysis, while addressing biases present in RNA-seq data that 
is not found using other techniques, namely that expected reads counts for a transcript is based on both the gene's level of expression, and the length of the transcript. The Wallenius approximation is used by GOSeq to approximate GO category enrichment and calculate p-values for each GO category being over represented among genes that were differentially expressed (DESeq2 padj $<=0.05$ ). These enrichment $\mathrm{p}$-values were corrected for multiple testing using the Benjamini-Hochberg Procedure.

Statistics. All statistics were generated using Graphpad Prism v6.0h. 


\section{Results}

Tbet expression in Tregs is required for survival of acute T. gondii infection

We investigated the role of Tbet in Tregs during Toxoplasma by administering 5 ME49 T. gondii cysts via oral gavage to both Foxp $3^{\mathrm{YFPCre}}$ and $T b x 21^{f f f}$-Foxp $3^{\mathrm{YFPCre}}$ mice. The acute phase of infection begins in the intestinal tract, and is marked by weight loss. We found a similar weight loss between Foxp3 $3^{\text {YFPCre }}$ and $T b x 21^{f f f}$-Foxp3 $3^{\text {YFPCre }}$ infected mice (Figure 1A). However, $\operatorname{Tb} \times 21^{f f f}-$ Foxp $3^{\text {YFPCre }}$ infected mice succumbed to infection at a significantly higher rate (87\%) than infected Foxp3 $3^{\text {YFPCre }}$ mice, where the majority survived through acute infection (Figure 1B). We first asked if $T b \times 21^{f / f}$-Foxp $3^{\text {YFPCre }}$ mice were succumbing to parasitemia because of an inability to control the infection. To this end, we harvested tissue from day 12 post-infected mice and used qPCR to quantify $T$. gondii DNA using the tandem repeat gene $B 1$. No differences were observed in parasite burden between mice in the thymus, lung, heart and ileum. There was significantly less parasite in the brains of $T b x 21^{f f f}$-Foxp $3^{\text {YFPCre }}$ mice versus Foxp $3^{\text {YFPCre }}$ controls (Figure 1C). These findings show that Tbet expression in Tregs is necessary for survival of acute T. gondii infection, and that it does not negatively impact immune control of $T$. gondii infection.

Tbx2 $1^{f f f}-$ Foxp $3^{\text {YFPCre }}$ mice exhibit severe pathology during acute T. gondii infection

Since uncontrolled parasite growth was not observed in $T b x 21^{f f f}-$ Foxp $3^{\mathrm{YFPCre}}$ mice, we turned to the host response to understand how Tbet expression in Tregs could promote host survival during acute infection. We analyzed biomarkers in serum associated with excessive inflammation to ascertain if acute organ failure was occurring in the absence of Treg-specific Tbet expression. A comprehensive metabolic panel was performed on blood freshly isolated 
from $T b x 21^{f f f}$-Foxp $3^{\text {YFPCre }}$ mice and Foxp $3^{\text {YFPCre }}$ control mice day 10 post-infection. Significantly decreased levels of glucose and albumin were observed in the $T b \times 21^{f f f}$-Foxp $3^{\mathrm{YFPCre}}$ mice. In addition, significantly higher levels of inorganic phosphate, cholesterol and blood urea nitrogen were measured in the $T b x 21^{f f}$-Foxp $3^{\mathrm{YFPCre}}$ mice (Figure 2A). These differences in the serum may be tied to liver and kidney damage, however when measuring ALT/AST levels we found no significant differences between the two groups of mice (data not shown). In addition to blood metabolic panels, a complete blood count was performed to determine if hematopoiesis was differentially altered in $T b x 21^{f f f}-$ Foxp $3^{\text {YFPCre }}$ mice compared to Foxp $3^{\text {YFPCre }}$ mice during acute infection. Total leukocytes, lymphocytes, eosinophils, and neutrophils were not significantly different. However, a significantly lower frequency and number of monocytes were observed within the blood of Tbx21 fff-Foxp3 $3^{\text {YFPCre }}$ (Figure 2B). This data suggests that in spite of the immune response controlling the infection, there was potentially systemic lethal immunopathology in Tbx2 $1^{f / f}$-Foxp3 ${ }^{\mathrm{YFPCre}}$ mice.

Treg-specific Tbet deficiency elevates systemic IFNy and TNF $\alpha$, but not T helper 1 populations during acute $\mathrm{T}$. gondii infection

We next examined the $\mathrm{CD}^{+} \mathrm{T}$ cell immune response in $T$. gondii infected $\operatorname{Tb} \times 21^{\mathrm{fff}}$-Foxp $3^{\mathrm{YFPCre}}$ mice compared with control Foxp $3^{\mathrm{YFPCr}}$ mice. Analysis of serum levels of IFN $\gamma$ and TNF $\alpha$, critical Th1 inflammatory cytokines that are important in host survival to $T$. gondii (25-29), were significantly increased in $T b \times 21^{f f f}$-Foxp $3^{\text {YFPCre }}$ mice compared to Foxp $3^{\text {YFPCre }}$ mice (Figure $3 \mathrm{~A}$ ). Next, $\mathrm{CD}^{+} \mathrm{T}$ cells were examined by FACS analysis for phenotype and absolute numbers in the spleen, mesenteric lymph nodes (mln), and small intestinal lamina propria (SILp). There was no difference in the absolute number of 
$\mathrm{CD} 4^{+} \mathrm{TCR} \beta^{+}$Foxp3- $^{-} \mathrm{T}$ cells (Figure 3B), or their expression of $\mathrm{Ki}^{+} 7^{+}$(Figure $3 \mathrm{C}$ ). The frequency of Tbet in $\mathrm{CD}^{+} \mathrm{TCR} \beta^{+}$Foxp3- $^{-} \mathrm{T}$ cells was similar in the mln and SILp but was reduced in the spleen in $T b x 2^{f f f}$-Foxp3 ${ }^{\text {YFPCre }}$ mice compared to Foxp3 ${ }^{\text {YFPCre }}$ mice (Figure 3D). We assessed the binding of the AS15 tetramer, which identifies $T$. gondii antigen specific $\mathrm{CD}^{+} \mathrm{T}$ cells. We found no difference in the frequency or absolute number of AS15 tetramer positive CD4 ${ }^{+} \mathrm{T}$ cells in the mln and SILp but both were reduced in the spleen in Tbx2 $1^{\mathrm{fff}}$-Foxp $3^{\mathrm{YFPCre}}$ mice compared to Foxp3 $3^{\text {YFPCre }}$ mice (Figure 3E). These results suggest that while expression of Tbet by Tregs is important for the restraint of wide-spread, fatal inflammation, it is largely dispensable for limiting the size and activity of the Th1 cell pool and cell parasite-specific CD4+ T cell responses in the gastrointestinal tract during acute infection.

Thet is required for the proliferation and accumulation of Tregs in the SILp during acute $\mathrm{T}$. gondii infection

We next examined $\mathrm{CD}^{+}{ }^{+} \mathrm{Foxp}^{+}$Tregs in the small intestinal lamina propria, mesenteric lymph nodes, and spleens of infected mice by FACS analysis. We found there was a reduced frequency of Tregs in $T b x 21^{f f f}$-Foxp $3^{\mathrm{YFPCre}}$ mice compared to Foxp $3^{\mathrm{YFPCre}}$ mice in the mesenteric lymph node, however no difference in the total number of Tregs was observed (Figure 4A). Tregs in the SILp were reduced in absolute numbers (Figure 4A left panel). Tregs from the SILp had reduced frequency of the proliferation marker Ki67 (Figure 4B left panel) and reduced absolute number of Ki67-expressing Tregs (Figure 4B right panel) in Tbx2 $1^{\mathrm{ff}}$-Foxp $3^{\mathrm{YFPCre}}$ mice compared to Foxp $3^{\mathrm{YFPCre}}$ mice. As expected, Tregs from $T b x 21^{f f f}$-Foxp $3^{\mathrm{YFPCre}}$ mice compared to Foxp $3^{\text {YFPCre }}$ mice expressed significantly less Tbet (Figure 4C). 
Since the increased mortality and immunopathology in the Tbx2 $1^{\text {fff }}$-Foxp $3^{\text {YFPCre }}$ mice were potentially indicative of inflammation associated with multi-organ failure, we also examined the $\mathrm{T}$ cell response in the liver. We found a small but significant decrease in the frequency of $\mathrm{CD}^{+}{ }^{+} \mathrm{TCR} \beta^{+}$Foxp $^{-} \mathrm{T}$ helper cells, but no difference in the total numbers. We find no difference in the number of antigen experienced CD4 ${ }^{+} \mathrm{Th} 1$ cells $\left(\mathrm{CD} 11 \mathrm{a}^{+} \mathrm{CD} 49 \mathrm{~d}^{+}\right)$, their expression of Tbet or the proliferative marker, Ki67 between Tbx $21^{f f f}$-Foxp $3^{\text {YFPCre }}$ mice and Foxp $3^{\text {YFPCre }}$ mice (Figure 5A). Analysis of $\mathrm{CD} 8^{+} \mathrm{TCR} \beta^{+}$in the liver showed no differences between the two groups of mice in frequency, numbers, activation status and proliferative capacity (Figure 5B). We examined the same parameters on Tregs in the liver of infected mice. Notably, we found that while small intestinal Tregs from $T b x 21^{f f f}$-Foxp $3^{\mathrm{YFPCre}}$ mice were reduced in both numbers and proliferation, there was a significant increase of both frequency and number of Tregs in the liver (Figure 5C). This data suggests that Tbet is needed for Treg accumulation at primary sites of acute infection, but secondary sites may not rely on Tbet for Treg accumulation.

$C D 4^{+} T$ cells participate in the enhanced immunopathology from acute $\mathrm{T}$. gondii infection in Tbx2 $1^{f f f}-F o x p 3^{Y F P C r e}$ mice

We next asked if the morbidity and mortality observed in the $T b x 21^{f f}$-Foxp $3^{\text {YFPCre }}$ mice was $\mathrm{T}$ cell mediated, which is observed in other strains of mice where immune regulation is altered $(30,31)$. The increased levels of serum IFN $\gamma$ and TNF $\alpha$ in (Figure 3A) prompted us to deplete CD4 T cells using the anti-CD4 monoclonal antibody, GK1.5. Mice were I.P. injected with $0.5 \mathrm{mg} / \mathrm{mL}$ anti-CD4 depleting or isotype antibody (clone LTF-2) before and during infection (30). Infected Foxp3 $3^{\text {YFPCre }}$ mice that received anti-CD4 antibody had similar survival 
compared with isotype control treated infected Foxp3 ${ }^{\mathrm{YFPCre}}$ mice. However, Tbx $21^{f f f}$-Foxp3 ${ }^{\mathrm{YFPCre}}$ mice that received anti-CD4 depleting antibodies were partially rescued from $T$. gondii infection compared with isotype control treated Tbx $21^{f f f}$-Foxp3 $3^{\mathrm{YFPCr}}$ mice (Figure 6A). We found no difference between Foxp $3^{\mathrm{YFPCre}}$ or $T b x 2^{\text {fff }}$-Foxp $3^{\mathrm{YFPCre}}$ mice treated with either isotype control or anti-CD4 antibodies and parasite burden (Figure 6B). We next determined if there was a reduction in the serum levels of IFN $\gamma$ or TNF $\alpha$ in Foxp $3^{\text {YFPCre }}$ mice compared with $T b \times 21^{f f f}-$ Foxp $3^{\text {YFPCre }}$ mice treated with isotype control or anti-CD4 antibodies. As observed previously, $T b \times 21^{f f f}$-Foxp3YFPCre mice had significantly higher serum levels of IFN $\gamma$ as well as heightened TNF $\alpha$ levels compared to Foxp3YFPCre mice. However, no marked differences in the levels of these cytokines were seen upon CD4 depletion (Figure 6C). The increased levels of IFN $\gamma$ and TNF $\alpha$ in Tbx $21^{f f f}-$ Foxp $3^{\text {YFPCre }}$ mice, despite anti-CD4 treatment, highlights the importance of fully functional Tregs to not only control $\mathrm{T}$ helper cells, but also other arms of immunity. The partial rescue of CD4-depleted $T b x 21^{f f}$-Foxp $3^{\mathrm{YFPCre}}$ mice implicates a role for $\mathrm{CD}^{+} \mathrm{T}$ cells in driving lethal immunopathology when Tregs cannot express Tbet during $T$. gondii infection.

Broad spectrum antibiotics ameliorates immunopathology from acute $\mathrm{T}$. gondii infection in $\mathrm{Tbx} 21^{\mathrm{f} / \mathrm{f}}-$ Foxp $3^{\text {YFPCre }}$ mice

Mice infected perorally with a high dose $T$. gondii succumbed to severe ileitis and small intestine immunopathology through Th1 associated proinflammatory cytokines (32-34). This acute Th1 immune response causes a shift in the gut commensals communities and can 
contribute to the morbundity and mortality of mice during acute $T$. gondii in genetically susceptible hosts $(32,35,36)$. Dysbiosis is attributed to specifically accumulated populations of the Gram-negative bacteria E. Coli, Bacteroides spp and other proinflammatory associated bacteria $(37,38)$. The use of broad spectrum antibiotics to deplete commensal gut flora rescues mice from systemic immunopathology during the acute stages of $T$. gondii infection $(37,38)$. To test if the lethal immunopathology in $T b \times 21^{f f f}$-Foxp3 $3^{\text {YFPCre }}$ mice was mediated by an over exuberant immune response to commensal flora, we administered water supplemented with broad spectrum antibiotics to both strains of mice 14 days prior to infection with T. gondii. Mice received water without antibiotics as controls. Mice were orally gavaged with 5 ME49 cysts and received continued antibiotic treatment until 21 days post-infection. Foxp $3^{\text {YFPCre }}$ mice showed no difference in survival between control water and antibiotic water (Figure 7A). The $\operatorname{Tb} \times 21^{\mathrm{fff}}$-Foxp $3^{\mathrm{YFPCre}}$ cohort that was administered antibiotic water survived significantly longer than the $T b \times 21^{f f}$-Foxp3 ${ }^{\text {YFPCre }}$ controls. Of note, $50 \%$ of the mice receiving antibiotics in the $\operatorname{Tb} \times 21^{f f f}$-Foxp3 ${ }^{\text {YFPCre }}$ group survived until day 65 post-infection (Figure 7A). We found no difference between Foxp $3^{\text {YFPCre }}$ mice mice that received control water or antibiotic water. $T b \times 21^{f f f}$-Foxp $3^{\text {YFPCre }}$ mice that received antibiotic water had reduced cyst burden compared to Foxp $3^{\text {YFPCre }}$ mice treated with antibiotic water (Figure 7B).

Since antibiotic treatment partially rescued the $T b \times 21^{f f}$-Foxp3 $3^{\text {YFPCre }}$ mice, we wanted to investigate the microbiota landscape and how subsequent dysbiosis caused by infection was altered between antibiotic treated and non-treated groups. To verify if the overall bacterial load was depleted, we compared 16s levels from before antibiotic treatment to the levels on day 7 post infection (Supplemental Figure 1). After 3 weeks of antibiotic administration in both 
Foxp $3^{\text {YFPCre }}$ and $T b x 21^{f f f}-$ Foxp $3^{\text {YFPCre }}$ groups, 16s was significantly lower on the day 7 post infection timepoint. This result confirms that bacterial load in the antibiotic treated groups was decreased as expected. To parse out the specific changes in bacterial populations, qPCR was performed using primers targeting unique 16s rRNA subunit gene in DNA to discriminate global bacterial changes of Enterobacteriacae family, Bacteroides family, Eubacterium rectale/Clostridium coccoides group (EREC), and E. coli species (24). Quantifying the changes of the microbiota was achieved by comparing pre-infection at day 0 and 14 days post-infection. Unfortunately, due to the nature of $T b \times 21^{f f f}$-Foxp $3^{\mathrm{YFPCre}}$ mice succumbing to infection, we lacked comparisons to the $T b x 21^{f f}$-Foxp $3^{\text {YFPCre }}$ water control group at day 14 . Therefore, $\operatorname{Tb} \times 21^{f f f}$-Foxp $3^{\text {YFPCre }}$ antibiotic water treated mice were compared with the Foxp3 ${ }^{\text {YFPCre }}$ water control group. We first asked if there were baseline differences between the four groups of mice prior to infection at day 0 , after mice had been pre-treated for 2-weeks with antibiotic water. Our results show a significant outgrowth of Enterobacteriaceae and a species of that family, E. coli in both antibiotic and treated groups. This increase was present in both antibiotic groups, but the Foxp3 $3^{\text {YFPCre }}$ antibiotic group had an even greater increase in Enterobacteriaceae and E. coli when compared to the $T b x 21^{f f f}$-Foxp3 $3^{\text {YFPCre }}$ antibiotic-treated samples. While Enterobacteriacae and $E$. coli were easily quantified in both antibiotic groups, we had difficulty detecting it in the Tbx $21^{f / f}-$ Foxp $3^{\text {YFPCre }}$ control group. Another distinction between groups was that the EREC population was detected at day 0 in the $T b \times 21^{f f f}$-Foxp $3^{\text {YFPCre }}$ controls but was depleted in their counterpart antibiotic groups.

Next, we examined the differences in bacterial populations at day 14 to assess changes within the infected mice. Our results showed a significant increase in the Bacteroides group that 
was specific to the $T b \times 21^{f f f}$-Foxp $3^{\text {YFPCre }}$ antibiotics group on day 14 of infection. The Bacteroides population was also absent within the $T b x 21^{f f f}$-Foxp $3^{\text {YFPCre }}$ antibiotic group prior to infection. Finally, we examined the consequences of antibiotic treatment on dysbiosis and any changes between Foxp3 $3^{\text {YFPCre }}$ control group at day 14 and antibiotic treated mice. There were significant decreases of EREC in both antibiotic groups at day 14 when compared to Foxp3 ${ }^{\text {YFPCre }}$ controls. Also, the distinct Bacteroides group at day 14 in the antibiotic $T b \times 21^{f f f}$-Foxp $3^{\text {YFPCre }}$ cohort was absent in the infected Foxp3 ${ }^{\text {YFPCre }}$ controls. Lastly, Enterobacteriacae and E. coli increase during infection was significantly higher in the Foxp $3^{\text {YFPCre }}$ antibiotic group compared to the controls. Although there was an increase of Enterobacteriaceae and E. coli at day 14 in the $\operatorname{Tb} \times 21^{\mathrm{fff}}$-Foxp $3^{\mathrm{YFPCre}}$ antibiotic group, this was not significantly different from day 14 Foxp3 $3^{\mathrm{YFPCre}}$ controls or antibiotics. The increase in Enterobacteriaceae and E. coli in the Tbx $21^{\mathrm{ff} f}$-Foxp3 ${ }^{\mathrm{YFPCre}}$ antibiotic cohort was significantly different at day 0 , but not at day 14 . The increase that was observed prior to infection could be due to antibiotics depleting the majority of bacteria and supports $E$. coli opportunistically blooming in comparison to other resident commensals $(37,38)$. Together, our data supports the idea that immunopathology induced by dysbiosis is exacerbated in $T b \times 21^{f f f}$-Foxp $3^{\mathrm{YFPCre}}$ mice infected with T. gondii.

\section{Tbet promotes Treg cell cycle progression and fitness}

We sought to investigate global genetic changes in Tregs during infection and how Tbet influences Treg gene expression. We isolated total RNA from FACS sorted splenic Tregs $\left(\mathrm{CD}^{+} \mathrm{YFP}^{+}\right) 10$ days post-infection from $T b x 2^{1^{f / f}-\mathrm{Foxp}} 3^{\mathrm{YFPCre}}$ and Foxp $3^{\mathrm{YFPCre}}$ mice for RNA sequencing. There were 399 genes that were upregulated and 576 that were downregulated in 
Tregs from $T b x 21^{f f f}$-Foxp3 $3^{\text {YFPCre }}$ compared with Foxp3 ${ }^{\text {YFPCre }}$ mice (Figure 8A). There are several differentially expressed genes of note that are downregulated between in infected Tbx21 $1^{f f f}$-Foxp $3^{\text {YFPCre }}$ compared to Foxp $3^{\text {YFPCre }}$ sort purified Tregs, including Tbx21, Miat, Nkg7, Gzmk, Ccl4, Ccl5, and Hipl. Differentially expressed genes that are upregulated in Tbet deficient Tregs include Hpgds, Illrn, Illrl Areg and Penk (Figure 8B). GOSeq analysis showed that several biological processes associated with cell cycle progression and mitotic processes are significantly enriched (Figure $8 \mathrm{C}$ ), which is consistent with the reduction in proliferation and accumulation of Tbet-deficient Tregs in our previously reported data (Figure 3) and (5). Taken together, Tbet drives the expression of several aspects of fitness, in addition to homing molecules (5), that promote the ability of Tregs to prevent the immunopathology caused by dysbiosis during acute $T$. gondii infection.

\section{Discussion}

We show that the capacity to express Tbet in Tregs is necessary for survival of the host during acute $T$. gondii infection, as the majority of $T b \times 21^{f f f}-\mathrm{Foxp} 3^{\mathrm{YFPCre}}$, succumbed to the acute infection. Importantly, this increased susceptibility to infection was not due to uncontrolled parasite replication. These findings suggest that these Tbet-expressing Tregs are not required for regulating the protective immune response directed at the parasite. While there were minimal differences between the $\mathrm{T}$ helper cells found in the spleen, mesenteric lymph node and small intestinal lamina propria, mice harboring Tbet-deficient Tregs showed significantly reduced frequency and numbers of Tregs in the mesenteric lymph node and small intestinal lamina propria, respectively, in agreement with previous findings (5). We also observed that the 
frequency of Ki67 expression in Tregs was reduced in the small intestinal lamina propria of Tbx $21^{\mathrm{fff}}$-Foxp $3^{\mathrm{YFPCre}}$ mice compared to Foxp $3^{\mathrm{YFPCre}}$ mice. Notably, serum IFN- $\gamma$ and TNF $\alpha$ levels were significantly elevated in infected $T b x 21^{f f f}$-Foxp $3^{\text {YFPCre }}$ compared to Foxp $3^{\text {YFPCre }}$ mice. These data present distinct differences when compared to global Tbet knockout mice, namely the loss of control of $T$. gondii replication and dissemination at peripheral sites during acute infection, and similar IFN- $\gamma$ production compared to WT mice (39).

Moreover, it has been shown previously that Tbet-deficient Tregs have similar in vitro suppressive capacities WT Th1-Tregs $(12,40)$. Interestingly, in models of T cell mediated colitis, Tbet is not required for their suppressive capacity $(21,22,40)$. This is in line with studies demonstrating that RoR $\gamma$ t-expressing Tregs are commensal specific and control intestinal inflammation $(41,42)$. Adding another layer to the understanding of Tbet-expressing Tregs, a recent study demonstrated that IFN $\gamma^{+}$Tbet $^{+}$Tregs promoted Th- 1 intestinal inflammation in the DSS colitis model (13). The differences between our findings and others could be explained by potential differences in the commensal flora between animal facilities, instigating inflammatory stimuli or the additional complexity of an ongoing infection in the gastrointestinal tract. Furthermore, Tbet is highly expressed in Tregs during T. gondii compared to other infections, which may alter its function in Tregs compared to Tregs expressing lower levels of Tbet (5, 6, 12, 14, 16, 19, 20). This is supported by data showing Tregs in a $T$. gondii infected environment are sensitive to IL-12 stimulation, resulting in Stat4 phosphorylation, while Tregs in a naive setting, or L. monocytogenes, are not IL-12 sensitive $(6,12)$. This sensitivity is Stat1-dependent and due to the sustained production of IL-12 and IL-27 in T. gondii infection (19). Prolonged Tbet expression in Tregs, however, appears to result in pathogenic Treg function and impair 
tissue remodeling programs during chronic infection of $T$. gondii of muscle (16-18). Together, our data shows distinct roles for Tregs during the acute response compared to the chronic response to $T$. gondii infection. It still remains to be fully explored how this prolonged Tbet expression may reprogram Tregs during later stages of infection.

The driving force of immune-mediated pathology in acute $T$. gondii infection is dysbiosis of the microbiota in the gastrointestinal tract $(24,37,32,35,43-45)$. Toxoplasma infection can perturb the integrity of the epithelial barrier and cause a leaky gut $(35,37,46,47)$. This over-exuberant immune response is thought to be largely driven by $\mathrm{CD}^{+} \mathrm{T}$ cells $(35,37)$. In agreement with this, both depletion of $\mathrm{CD}^{+} \mathrm{T}$ cells and treatment with broad-spectrum antibiotics improved the disease course in $T b x 21^{f f f}-$ Foxp $3{ }^{\mathrm{YFPCre}}$ compared to Foxp $3^{\mathrm{YFPCre}}$ mice. It is now well recognized that Tregs must adapt within the inflammatory environment in order to function and prevent this collateral damage. Their role in suppressing this damage from the parasite specific Th1-mediated immune response during $T$. gondii infection has been documented (48-50). Our study highlights a role for Tbet driving several aspects of fitness that promotes the ability of Tregs to dampen the immunopathology caused by dysbiosis during acute T. gondii infection. It remains to be determined the role of Tbet expression in Tregs during the chronic phase of infection in skeletal muscle and other tissues. 


\section{Conflicts of Interest}

The authors declare no competing financial interests in relation to the work described.

\section{Acknowledgements}

Research reported in this publication was supported by the National Institute of Allergy and Infectious Diseases of the NIH under award number R21AI128284 (to EAW) and The Crohn's and Colitis Foundation of America (ref \#278937 to EAW). We thank the Confocal Imaging and Flow Cytometry Core, and the Genomics and Bioinformatics Core at the University at Buffalo, the National Institutes of Health Tetramer Core Facility for the T. gondii ME49 hypothetical protein tetramers, and Dr. Michael Grigg for generously providing the RFP-expressing ME49 parasite. We thank Dr. Joseph Barbi for his helpful discussion and critical reading of this article. 


\section{References}

1. Josefowicz, S. Z., L.-F. Lu, and A. Y. Rudensky. 2012. Regulatory T Cells: Mechanisms of Differentiation and Function. Annu. Rev. Immunol. 30: 531-564.

2. Kim, J. M., J. P. Rasmussen, and A. Y. Rudensky. 2007. Regulatory T cells prevent catastrophic autoimmunity throughout the lifespan of mice. Nat. Immunol. 8: 191-197. 3. Okeke, E. B., and J. E. Uzonna. 2019. The Pivotal Role of Regulatory T Cells in the Regulation of Innate Immune Cells. Front. Immunol. 10: 680.

4. Zheng, Y., A. Chaudhry, A. Kas, P. deRoos, J. M. Kim, T.-T. Chu, L. Corcoran, P. Treuting, U. Klein, and A. Y. Rudensky. 2009. Regulatory T-cell suppressor program co-opts transcription factor IRF4 to control T(H)2 responses. Nature 458: 351-356.

5. Koch, M. A., G. Tucker-Heard, N. R. Perdue, J. R. Killebrew, K. B. Urdahl, and D. J. Campbell. 2009. The transcription factor T-bet controls regulatory $\mathrm{T}$ cell homeostasis and function during type 1 inflammation. Nat. Immunol. 10: 595-602.

6. Koch, M. A., K. R. Thomas, N. R. Perdue, K. S. Smigiel, S. Srivastava, and D. J. Campbell. 2012. T-bet+ Treg Cells Undergo Abortive Th1 Cell Differentiation due to Impaired Expression of IL-12 Receptor $\beta 2$. Immunity 37: 501-510.

7. Chaudhry, A., D. Rudra, P. Treuting, R. M. Samstein, Y. Liang, A. Kas, and A. Y. Rudensky. 2009. CD4+ regulatory T cells control TH17 responses in a Stat3-dependent manner.

Science 326: 986-991.

8. Chung, Y., S. Tanaka, F. Chu, R. I. Nurieva, G. J. Martinez, S. Rawal, Y.-H. Wang, H. Lim, J. M. Reynolds, X. Zhou, H. Fan, Z. Liu, S. S. Neelapu, and C. Dong. 2011. Follicular regulatory T cells expressing Foxp3 and Bcl-6 suppress germinal center reactions. Nat. Med. 17:

983-988.

9. Wang, Y., M. A. Su, and Y. Y. Wan. 2011. An essential role of the transcription factor GATA-3 for the function of regulatory T cells. Immunity 35: 337-348.

10. Linterman, M. A., W. Pierson, S. K. Lee, A. Kallies, S. Kawamoto, T. F. Rayner, M. Srivastava, D. P. Divekar, L. Beaton, J. J. Hogan, S. Fagarasan, A. Liston, K. G. C. Smith, and C. G. Vinuesa. 2011. Foxp3+ follicular regulatory T cells control the germinal center response. Nat. Med. 17: $975-982$.

11. Wohlfert, E. A., J. R. Grainger, N. Bouladoux, J. E. Konkel, G. Oldenhove, C. H. Ribeiro, J. A. Hall, R. Yagi, S. Naik, R. Bhairavabhotla, W. E. Paul, R. Bosselut, G. Wei, K. Zhao, M. Oukka, J. Zhu, and Y. Belkaid. 2011. GATA3 controls Foxp3 ${ }^{+}$regulatory T cell fate during inflammation in mice. J. Clin. Invest. 121: 4503-4515.

12. Oldenhove, G., N. Bouladoux, E. A. Wohlfert, J. A. Hall, D. Chou, L. Dos santos, S. O’Brien, R. Blank, E. Lamb, S. Natarajan, R. Kastenmayer, C. Hunter, M. E. Grigg, and Y. Belkaid. 2009. Decrease of Foxp3+ Treg Cell Number and Acquisition of Effector Cell Phenotype during Lethal Infection. Immunity 31: 772-786.

13. Di Giovangiulio, M., A. Rizzo, E. Franzè, F. Caprioli, F. Facciotti, S. Onali, A. Favale, C. Stolfi, H.-J. Fehling, G. Monteleone, and M. C. Fantini. 2019. Tbet Expression in Regulatory T Cells Is Required to Initiate Th1-Mediated Colitis. Front. Immunol. 10.

14. Levine, A. G., A. Mendoza, S. Hemmers, B. Moltedo, R. E. Niec, M. Schizas, B. E. Hoyos, E. V. Putintseva, A. Chaudhry, S. Dikiy, S. Fujisawa, D. M. Chudakov, P. M. Treuting, and A. Y. Rudensky. 2017. Stability and function of regulatory T cells expressing the transcription 
factor T-bet. Nature 546: 421.

15. Wohlfert, E., and Y. Belkaid. 2010. Plasticity of Treg at infected sites. Mucosal Immunol. 3: 213-215.

16. Jin, R. M., S. J. Blair, J. Warunek, R. R. Heffner, I. J. Blader, and E. A. Wohlfert. 2017. Regulatory T Cells Promote Myositis and Muscle Damage in Toxoplasma gondii Infection. J. Immunol. 198: 352-362.

17. Jin, R. M., J. Warunek, and E. A. Wohlfert. 2018. Therapeutic Administration of IL-10 and Amphiregulin Alleviates Chronic Skeletal Muscle Inflammation and Damage Induced by Infection. ImmunoHorizons 2: 142-154.

18. Jin, R. M., J. Warunek, and E. A. Wohlfert. 2018. Chronic infection stunts macrophage heterogeneity and disrupts immune-mediated myogenesis. JCI Insight 3.

19. Hall, A. O., D. P. Beiting, C. Tato, B. John, G. Oldenhove, C. G. Lombana, G. H. Pritchard, J. S. Silver, N. Bouladoux, J. S. Stumhofer, T. H. Harris, J. Grainger, E. D. T. Wojno, S. Wagage, D. S. Roos, P. Scott, L. A. Turka, S. Cherry, S. L. Reiner, D. Cua, Y. Belkaid, M. M. Elloso, and C. A. Hunter. 2012. The Cytokines Interleukin 27 and Interferon- $\gamma$ Promote Distinct Treg Cell Populations Required to Limit Infection-Induced Pathology. Immunity 37: 511-523. 20. O’Brien, C. A., C. Overall, C. Konradt, A. C. O. Hall, N. W. Hayes, S. Wagage, B. John, D. A. Christian, C. A. Hunter, and T. H. Harris. 2017. CD11c-Expressing Cells Affect Regulatory T Cell Behavior in the Meninges during Central Nervous System Infection. J. Immunol. 198: 4054-4061.

21. McPherson, R. C., D. G. Turner, I. Mair, R. A. O'Connor, and S. M. Anderton. 2015. T-bet Expression by Foxp3+ T Regulatory Cells is Not Essential for Their Suppressive Function in CNS Autoimmune Disease or Colitis. Front. Immunol. 6.

22. Yu, F., S. Sharma, J. Edwards, L. Feigenbaum, and J. Zhu. 2015. Dynamic expression of transcription factors T-bet and GATA-3 by regulatory T cells maintains immunotolerance. Nat. Immunol. 16: 197-206.

23. Rakoff-Nahoum, S., J. Paglino, F. Eslami-Varzaneh, S. Edberg, and R. Medzhitov. 2004. Recognition of Commensal Microflora by Toll-Like Receptors Is Required for Intestinal Homeostasis. Cell 118: 229-241.

24. Molloy, M. J., J. R. Grainger, N. Bouladoux, T. W. Hand, L. Y. Koo, S. Naik, M. Quinones, A. K. Dzutsev, J.-L. Gao, G. Trinchieri, P. M. Murphy, and Y. Belkaid. 2013. Intraluminal containment of commensal outgrowth in the gut during infection-induced dysbiosis. Cell Host Microbe 14: 318-328.

25. Suzuki, Y., M. A. Orellana, R. D. Schreiber, and J. S. Remington. 1988. Interferon-gamma: the major mediator of resistance against Toxoplasma gondii. Science 240: 516-518. 26. Hunter, C. A., C. S. Subauste, V. H. Van Cleave, and J. S. Remington. 1994. Production of gamma interferon by natural killer cells from Toxoplasma gondii-infected SCID mice: regulation by interleukin-10, interleukin-12, and tumor necrosis factor alpha. Infect. Immun. 62: 2818-2824.

27. Deckert-Schlüter, M., H. Bluethmann, A. Rang, H. Hof, and D. Schlüter. 1998. Crucial Role of TNF Receptor Type 1 (p55), But Not of TNF Receptor Type 2 (p75), in Murine Toxoplasmosis. J. Immunol. 160: 3427-3436.

28. Yap, G. S., T. Scharton-Kersten, H. Charest, and A. Sher. 1998. Decreased Resistance of TNF Receptor p55- and p75-Deficient Mice to Chronic Toxoplasmosis Despite Normal Activation of Inducible Nitric Oxide Synthase In Vivo. J. Immunol. 160: 1340-1345. 
29. Schlüter, D., L.-Y. Kwok, S. Lütjen, S. Soltek, S. Hoffmann, H. Körner, and M. Deckert. 2003. Both Lymphotoxin- $\alpha$ and TNF Are Crucial for Control of Toxoplasma gondii in the Central Nervous System. J. Immunol. 170: 6172-6182.

30. Gazzinelli, R. T., M. Wysocka, S. Hieny, T. Scharton-Kersten, A. Cheever, R. Kühn, W. Müller, G. Trinchieri, and A. Sher. 1996. In the absence of endogenous IL-10, mice acutely infected with Toxoplasma gondii succumb to a lethal immune response dependent on CD4+ T cells and accompanied by overproduction of IL-12, IFN-gamma and TNF-alpha. J. Immunol. 157: 798-805.

31. Villarino, A., L. Hibbert, L. Lieberman, E. Wilson, T. Mak, H. Yoshida, R. A. Kastelein, C. Saris, and C. A. Hunter. 2003. The IL-27R (WSX-1) Is Required to Suppress T Cell Hyperactivity during Infection. Immunity 19: 645-655.

32. Liesenfeld, O., J. Kosek, J. S. Remington, and Y. Suzuki. 1996. Association of CD4+ T cell-dependent, interferon-gamma-mediated necrosis of the small intestine with genetic susceptibility of mice to peroral infection with Toxoplasma gondii. J. Exp. Med. 184: 597-607.

33. Liesenfeld, 0. 2002. Oral infection of C57BL/6 mice with Toxoplasma gondii: a new model of inflammatory bowel disease? J. Infect. Dis. 185 Suppl 1: S96-101.

34. Egan, C. E., S. B. Cohen, and E. Y. Denkers. 2012. Insights into inflammatory bowel disease using Toxoplasma gondii as an infectious trigger. Immunol. Cell Biol. 90: 668-675. 35. Raetz, M., S. Hwang, C. Wilhelm, D. Kirkland, A. Benson, C. Sturge, J. Mirpuri, S. Vaishnava, B. Hou, A. L. DeFranco, C. J. Gilpin, L. V. Hooper, and F. Yarovinsky. 2013. Parasite-induced TH1 cells and intestinal dysbiosis cooperate in IFN- $\gamma$-dependent elimination of Paneth cells. Nat. Immunol. 14: 136-142.

36. Burger, E., A. Araujo, A. López-Yglesias, M. W. Rajala, L. Geng, B. Levine, L. V. Hooper, E. Burstein, and F. Yarovinsky. 2018. Loss of Paneth Cell Autophagy Causes Acute Susceptibility to Toxoplasma gondii -Mediated Inflammation. Cell Host Microbe 23: 177-190.e4.

37. Heimesaat, M. M., S. Bereswill, A. Fischer, D. Fuchs, D. Struck, J. Niebergall, H.-K. Jahn, I. R. Dunay, A. Moter, D. M. Gescher, R. R. Schumann, U. B. Göbel, and O. Liesenfeld. 2006. Gram-Negative Bacteria Aggravate Murine Small Intestinal Th1-Type Immunopathology following Oral Infection with Toxoplasma gondii. J. Immunol. 177: 8785-8795.

38. Craven, M., C. E. Egan, S. E. Dowd, S. P. McDonough, B. Dogan, E. Y. Denkers, D. Bowman, E. J. Scherl, and K. W. Simpson. 2012. Inflammation Drives Dysbiosis and Bacterial Invasion in Murine Models of Ileal Crohn's Disease. PLoS ONE 7.

39. Pritchard, G. H., A. O. Hall, D. A. Christian, S. Wagage, Q. Fang, G. Muallem, B. John, A. G. Zaretsky, W. G. Dunn, J. Perrigoue, S. L. Reiner, and C. A. Hunter. 2015. Diverse Roles for T-bet in the Effector Responses Required for Resistance to Infection. J. Immunol. 194: 1131-1140. 40. Feng, T., A. T. Cao, C. T. Weaver, C. O. Elson, and Y. Cong. 2011. Interleukin-12 Converts Foxp3+ Regulatory T Cells to Interferon- $\gamma$-Producing Foxp3+ T Cells That Inhibit Colitis. Gastroenterology 140: 2031-2043.

41. Ohnmacht, C., J.-H. Park, S. Cording, J. B. Wing, K. Atarashi, Y. Obata, V. Gaboriau-Routhiau, R. Marques, S. Dulauroy, M. Fedoseeva, M. Busslinger, N.

Cerf-Bensussan, I. G. Boneca, D. Voehringer, K. Hase, K. Honda, S. Sakaguchi, and G. Eberl. 2015. MUCOSAL IMMUNOLOGY. The microbiota regulates type 2 immunity through ROR $\gamma \mathrm{t}^{+}$ T cells. Science 349: 989-993. 
42. Sefik, E., N. Geva-Zatorsky, S. Oh, L. Konnikova, D. Zemmour, A. M. McGuire, D. Burzyn, A. Ortiz-Lopez, M. Lobera, J. Yang, S. Ghosh, A. Earl, S. B. Snapper, R. Jupp, D. Kasper, D. Mathis, and C. Benoist. 2015. Individual intestinal symbionts induce a distinct population of ROR $\gamma+$ regulatory T cells. Science 349: 993-997.

43. Bereswill, S., M. Muñoz, A. Fischer, R. Plickert, L.-M. Haag, B. Otto, A. A. Kühl, C. Loddenkemper, U. B. Göbel, and M. M. Heimesaat. 2010. Anti-Inflammatory Effects of Resveratrol, Curcumin and Simvastatin in Acute Small Intestinal Inflammation. PLoS ONE 5. 44. Bereswill, S., A. A. Kühl, M. Alutis, A. Fischer, L. Möhle, D. Struck, O. Liesenfeld, U. B. Göbel, I. R. Dunay, and M. M. Heimesaat. 2014. The impact of Toll-like-receptor-9 on intestinal microbiota composition and extra-intestinal sequelae in experimental Toxoplasma gondii induced ileitis. Gut Pathog. 6: 19.

45. Heimesaat, M. M., I. R. Dunay, M. Alutis, A. Fischer, L. Möhle, U. B. Göbel, A. A. Kühl, and S. Bereswill. 2014. Nucleotide-Oligomerization-Domain-2 Affects Commensal Gut Microbiota Composition and Intracerebral Immunopathology in Acute Toxoplasma gondii Induced Murine Ileitis. PLOS ONE 9: e105120.

46. McLeod, R., P. Eisenhauer, D. Mack, C. Brown, G. Filice, and G. Spitalny. 1989. Immune responses associated with early survival after peroral infection with Toxoplasma gondii. $J$. Immunol. 142: 3247-3255.

47. Schreiner, M., and O. Liesenfeld. 2009. Small intestinal inflammation following oral infection with Toxoplasma gondii does not occur exclusively in C57BL/6 mice: review of 70 reports from the literature. Mem. Inst. Oswaldo Cruz 104: 221-233.

48. Morampudi, V., S. De Craeye, A. Le Moine, S. Detienne, M. Y. Braun, and S. D’Souza. 2011. Partial depletion of CD4+CD25+Foxp3+ T regulatory cells significantly increases morbidity during acute phase Toxoplasma gondii infection in resistant BALB/c mice. Microbes Infect. 13: 394-404.

49. Tenorio, E. P., J. E. Olguín, J. Fernández, P. Vieyra, and R. Saavedra. 2010. Reduction of Foxp3+ Cells by Depletion with the PC61 mAb Induces Mortality in Resistant BALB/c Mice Infected with Toxoplasma gondii. J. Biomed. Biotechnol. 2010.

50. Couper, K. N., P. A. Lanthier, G. Perona-Wright, L. W. Kummer, W. Chen, S. T. Smiley, M. Mohrs, and L. L. Johnson. 2009. Anti-CD25 Antibody-Mediated Depletion of Effector T Cell Populations Enhances Susceptibility of Mice to Acute but Not Chronic Toxoplasma gondii Infection. J. Immunol. 182: 3985-3994. 


\section{Figure Legends}

Figure 1. Tbet expression in Tregs is required for survival to T. gondii infection. Groups of Foxp $3^{\mathrm{YFPCre}}$ and $T b x 21^{\mathrm{f} / \mathrm{f}}$-Foxp3 $3^{\mathrm{YFP} r e}$ mice were orally infected with five ME49 ${ }^{\mathrm{RFP}} T$. gondii cysts. Tissues were isolated at $12 \mathrm{~d}$ postinfection and parasite burden was quantified. (A) Percent weight loss and (B) survival curve summary from four experiments using male and female mice. (C) Tissues from day 12 infected Foxp3 $3^{\text {YFPCre }}$ and $T b x 21^{\mathrm{f} / \mathrm{f}}-\mathrm{Foxp} 3^{\mathrm{YFP} r \mathrm{e}}$ mice were harvested to extract gDNA and analyzed for parasite burden using $T$. gondii-specific gene, B1. Results are cumulative of four experiments with $n \geq 3$ mice per group per experiment. A cumulative total of $\mathrm{n} \geq 16$ per group $(\mathrm{A}, \mathrm{B})$ and $\mathrm{n} \geq 9(\mathrm{C})$; error bars $=\mathrm{SD} .{ }^{*} \mathrm{p}<0.05, * * * * \mathrm{p}<0.0001$, Log-rank (Mantel-Cox) Test (B), Student $t$ test (C).

Figure 2. Acute $T$. gondii infection causes immunopathology and metabolic shift indicative of systemic damage in $\boldsymbol{T b} \boldsymbol{x} 21^{\mathrm{f} / \mathrm{f}}-\mathbf{F o x p} 3^{\mathrm{YFP} P r e}$ mice. Groups of Foxp3 $3^{\mathrm{YFPC}}$ and $T b \times 21^{\mathrm{f} / \mathrm{f}}-$ Foxp $3^{\mathrm{YFP} r e}$ mice were orally infected with five ME49 $9^{\mathrm{RFP}} T$. gondii cysts. Mice were euthanized $10 \mathrm{~d}$ postinfection using $\mathrm{CO}_{2}$ and fresh blood was isolated by cardiac puncture to perform a comprehensive metabolic panel and complete blood count. (A) Blood chemistry assay was performed $10 \mathrm{~d}$ postinfection looking at liver and kidney function. Dashed lines are reference values for uninfected mice (B) Complete blood counts $10 \mathrm{~d}$ postinfection quantifying absolute numbers of leukocytes and (C) pie graphs of percent leukocytes in the blood. Results are cumulative of 2 experiments with $n \geq 5$ per group per experiment. A cumulative total of $n \geq$ 10 per group (A-C). Error bars $=\mathrm{SD} .{ }^{*} \mathrm{p}<0.05,{ }^{*} \mathrm{p}<.01,{ }^{*} * \mathrm{p}<0.001,{ }^{*} * * * \mathrm{p}<0.0001$, Student $t$ test. 
Figure 3. T helper cells recognize $T$. gondii in similar fashion during acute infection. Groups of Foxp3 $3^{\mathrm{YFPCre}}$ and $T b x 21^{\mathrm{f} / \mathrm{f}}$-Foxp3 $3^{\mathrm{YFP} \text { cre }}$ mice were orally infected with five ME49 ${ }^{\mathrm{RFP}}$ T. gondii cysts. Lymphocytes from the spleen, mesenteric lymph nodes $(\mathrm{mln})$, and small intestinal lamina propria (SILp) were isolated on 12-14 d postinfection. CD4+ $\mathrm{T}$ helper cells were stained and analyzed using flow cytometry. (A) ELISA was performed to quantify IFN $\gamma$ (left) and TNF $\alpha$ (right) in sera 10-12 d postinfection. (B) Quantification of absolute total number of $\mathrm{CD}^{+} \mathrm{T}$ helper cells, gated on live TCR $\beta^{+} \mathrm{CD}^{+}{ }^{+}$Foxp3 $3^{-}$cells. (C) Percentages of $\mathrm{Ki}^{+} 7^{+}$or $\mathrm{Tbet}^{+} \mathrm{T}$ helper cells in spleen, mln, and SILp. (D) Representative FACs plots of T. gondii tetramer staining, gated on live $\mathrm{TCR} \beta^{+} \mathrm{CD} 4^{+}$Foxp3- looking at $\mathrm{T}$ helper coexpression of Tbet and tetramer in SILp. (E) Absolute (left) and frequency (right) quantification of Th1 T. gondii tetramer staining, gated on live $\mathrm{TCR} \beta^{+} \mathrm{CD} 4+$ Foxp3 $^{-}$Tbet $^{+}$Tetramer $^{+} . \mathrm{n} \geq 3$ per group, cumulative of 3 experiments. A cumulative total of $\mathrm{n} \geq 6$ per group. Error bars $=\mathrm{SD} .{ }^{*} \mathrm{p}<0.01,{ }^{*} \mathrm{p}<0.05$, ANOVA with Tukey multiple comparison test.

Figure 4. Comparison between Tregs during acute infection. (A) Quantification of Treg frequency (left) and absolute (right), gated on live $\mathrm{TCR} \beta^{+} \mathrm{CD} 4^{+} \mathrm{Foxp} 3^{+}$in the spleen, mesenteric lymph node (mln) and small intestinal lamina propria (SILp) on day 12-14 dpi. (B) Frequency (left) and absolute (right) of Ki67+ Tregs. (C) Frequency (left) and absolute (right) of Tbet ${ }^{+}$ Tregs. Results are cumulative of at least 3 experiments with $n \geq 3$ per group. A cumulative total of $\mathrm{n} \geq 7$ per group. Error bars $=\mathrm{SD} .{ }^{*} \mathrm{p}<0.05,{ }^{*} \mathrm{p}<0.01, * * * * \mathrm{p}<0.0001$, ANOVA with Tukey multiple comparison test (C-D). 
Figure 5. Differences in Tregs but not CD4 or CD8 $\mathrm{T}$ cells in the liver during acute infection

(A) Quantification of $\mathrm{T}$ helper cells gated on live $\mathrm{CD}^{+} \mathrm{TCRb}^{+} \mathrm{Foxp} 3^{-}$in the liver on day 12 dpi.

(B) or $\mathrm{CD}^{+} \mathrm{TCRb}^{+}$or (C) Tregs, $\mathrm{CD}^{+} \mathrm{TCRb}^{+} \mathrm{Foxp}^{+}$. Results are cumulative of 2 experiments with $\mathrm{n} \geq 3$ in each group. Error bars $=\mathrm{SD} .{ }^{*} \mathrm{p}<0.05,{ }^{*} \mathrm{p}<0.01,{ }^{* * *} \mathrm{p}<0.0001$, Student's t-Test.

Figure 6. CD4 depletion partially rescues $T b x 21^{\mathrm{f} / \mathrm{f}}$-Foxp3 $3^{\mathrm{YPP} r e}$ mice from succumbing to $T$. gondii infection. Groups of Foxp $3^{\mathrm{YFPCre}}$ and $T b x 21^{\mathrm{f} / \mathrm{f}}$-Foxp $3^{\mathrm{YFPcre}}$ mice were I.P. injected with anti-CD4 depleting antibody or isotype control before and after infection on days $-5,-1,0,+5$, $+14,+19$. All mice were orally infected with five ME49 ${ }^{\mathrm{RFP}}$ T. gondii cysts. (A) Survival curve from mice orally infected with five ME49 ${ }^{\mathrm{RFP}}$ cysts and I.P. injected with $0.5 \mathrm{mg} / \mathrm{mL}$ anti-CD4 depleting antibody or isotype control. (B) Parasite burden in the brain at day 42 postinfection, quantified by DNA extraction and using qPCR to amplify $T$. gondii Bl gene. (C) Cytometric Bead Array to quantify IFN $\gamma$ (left) and TNF $\alpha$ (right) serum cytokine levels on 9-10 d postinfection. Survival curve is cumulative of four experiments with $n \geq 4$ per group per experiment. CBA is cumulative of two experiments with $n \geq 3$ per group per experiment. A cumulative total of $n \geq 5$ Foxp $3^{\text {YFPCre }}$ and $n \geq 15$ Tbx $21^{\mathrm{f} / \mathrm{f}}$-Foxp $3^{\text {YFPcre }}$ mice were used in the survival curve (A). A cumulative total of $n \geq 4$ mice per group (B-C). Error bars $=$ SD. ${ }^{*} p<$ $0.05,{ }^{* *} \mathrm{p}<0.01 * * * \mathrm{p}<0.001, * * * * \mathrm{p}<0.0001$, Log-rank (Mantel-Cox) Test (A) ANOVA with Tukey multiple-comparison test $(\mathrm{B}, \mathrm{C})$

Figure 7. Commensals contribute to the mortality of $T b x 21^{\mathrm{f} / \mathrm{f}}-\mathrm{Foxp} 3^{\mathrm{YFP} \text { cre }}$ during infection. Foxp $3^{\text {YFPCre }}$ and $T b \times 21^{\mathrm{f} / \mathrm{f}}$-Foxp3 $3^{\mathrm{YFP} c r e}$ were treated with broad spectrum antibiotic water containing ampicillin $1 \mathrm{~g} / \mathrm{L}$, neomycin $1 \mathrm{~g} / \mathrm{L}$, metronidazole $1 \mathrm{~g} / \mathrm{L}$, vancomycin $500 \mathrm{mg} / \mathrm{L}$ and Splenda $3 \mathrm{~g} / \mathrm{L}$. 
antibiotic water was administered in drinking bottles ad libitum for 2 weeks prior and 3 weeks after infection with $T$. gondii. Fecal samples were collected weekly to analyze bacterial populations. (A) Survival curve of antibiotic treated and water control mice after being infected with five ME49 ${ }^{\mathrm{RFP}}$ cysts with a 65 day postinfection endpoint. (B) ME49 ${ }^{\mathrm{RFP}}$ cyst counts from the brain homogenate on day 65 postinfection. (C) qPCR on DNA to semiquantitatively detect the 16s gene in fecal pellets collected for each of the following bacterial populations: Bacteroides, Eubacterium rectale/Clostridium coccoides (EREC), Enterobacteriaceae, and Escherichia coli (E.coli). Foxp3 ${ }^{\text {YFPcre }}$ untreated control mice were used as reference. Results are cumulative of three experiments with $n \geq 3$ per group per experiment. A cumulative total of $n \geq 9$ per group (A), $n \geq 4$ (B) and $n \geq 6$ except for Tbet water controls (C) Error bars $=$ SD. $* * * * p<0.0001,{ }^{*} p$ $<0.05$, Mantel-cox log-rank test (A), ANOVA with Tukey multiple-comparison test (C).

Figure 8. RNA-seq analysis shows that Tbet in Tregs governs a host of genes associated with fitness for Tregs during Th1 inflammation. Tregs were sorted from $9 \mathrm{~d}$ post-infected Foxp3 $3^{\text {YFPCre }}$ and $T b x 21^{\mathrm{f} / \mathrm{f}}-\mathrm{Foxp} 3^{\mathrm{YFPCre}}$ mice. RNA was isolated from the purified Tregs and RNA-Sequencing was performed. 3 mice of each genotype were combined per experiment and a total of three independent experiments were analyzed. (A) Heatmap of differentially expressed genes. (B) Volcano Plot highlighting differential genes in $T b \times 21^{\mathrm{f} / \mathrm{f}}-\mathrm{Foxp} 3^{\mathrm{YFPCre}}$ using Foxp3 ${ }^{\mathrm{YFPCre}}$ as reference. The most significantly regulated genes are in red and calculated using DESeq2. (C) GoSeq analysis of the top pathways in biological processes, cell cycle and metabolic function. 
bioRxiv preprint dol: https://doi.org/10.1101/2021.09.03.458860; this version posted September 4, 2021. The copyright holder for this preprint (which was not certified by peer review) is the author/funder, who has granted bioRxiv a license to display the preprint in perpetuity. It is made available under aCC-BY-NC-ND 4.0 International license.

Figure 1.

A Weight Curve

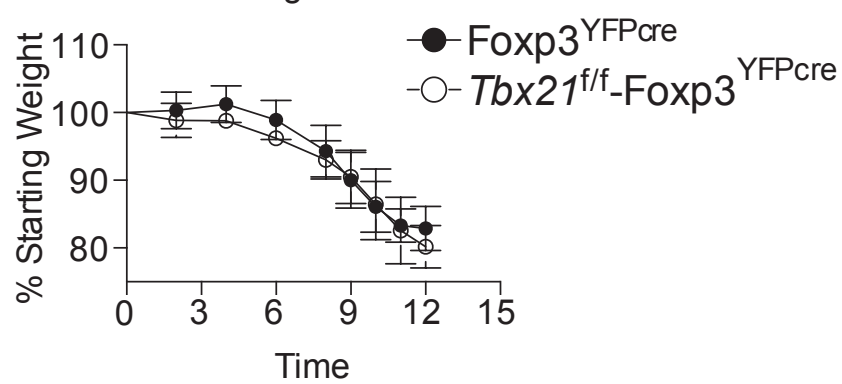

B

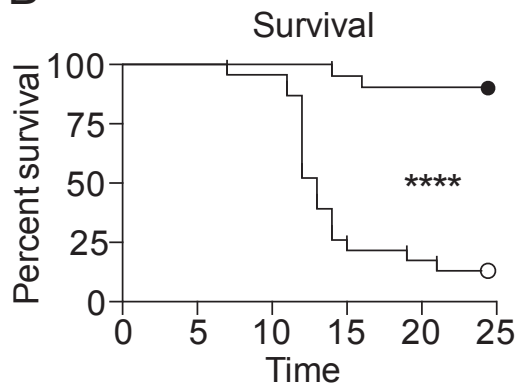

C
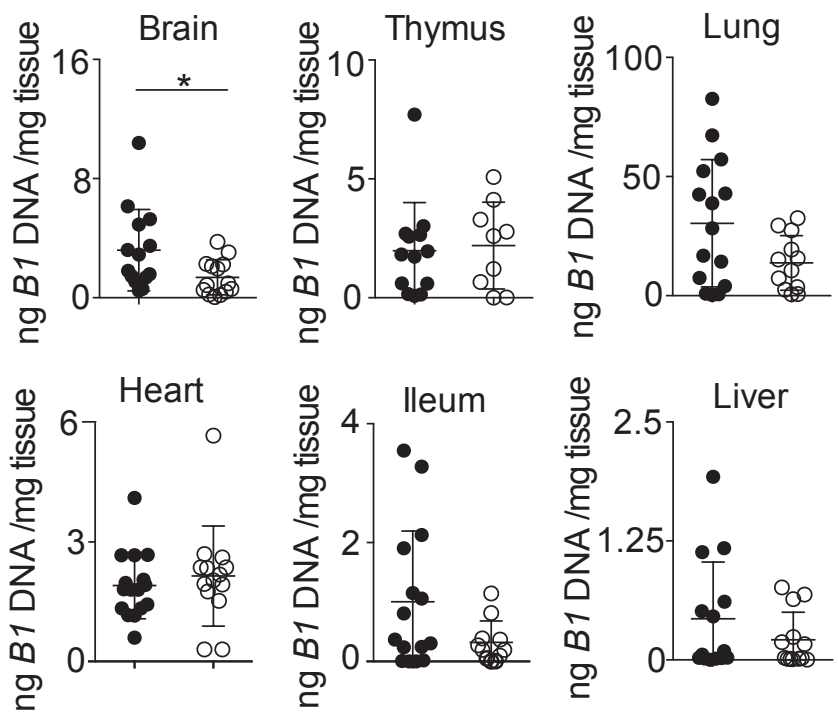
bioRxiv preprint doi: https://doi.org/10.1101/2021.09.03.458860; this version posted September 4, 2021. The copyright holder for this preprint (which was not certified by peer review) is the author/funder, who has granted bioRxiv a license to display the preprint in perpetuity. It is made available under aCC-BY-NC-ND 4.0 International license.

Figure 2.

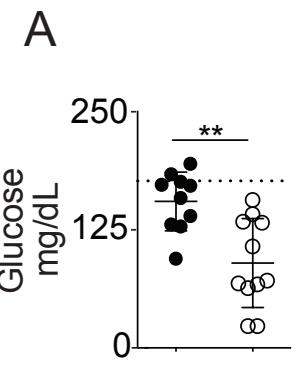

B
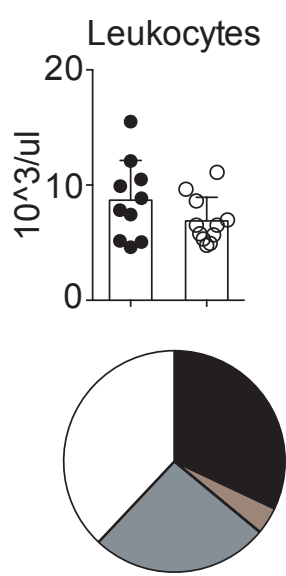
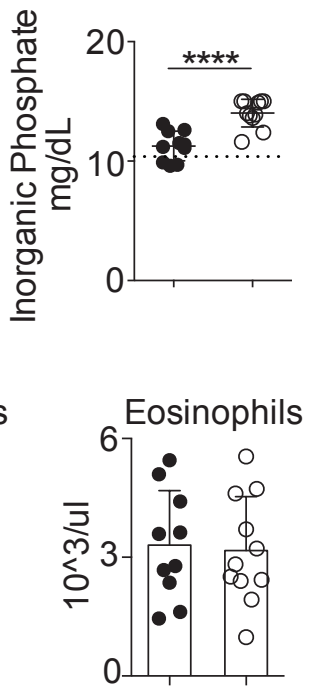

Foxp3 $3^{\text {YFPCre }}$

- Neutrophils 32\%

- Lymphocytes $4 \%$ 口Eosinophils $38 \%$ 口Monocytes $26 \%$
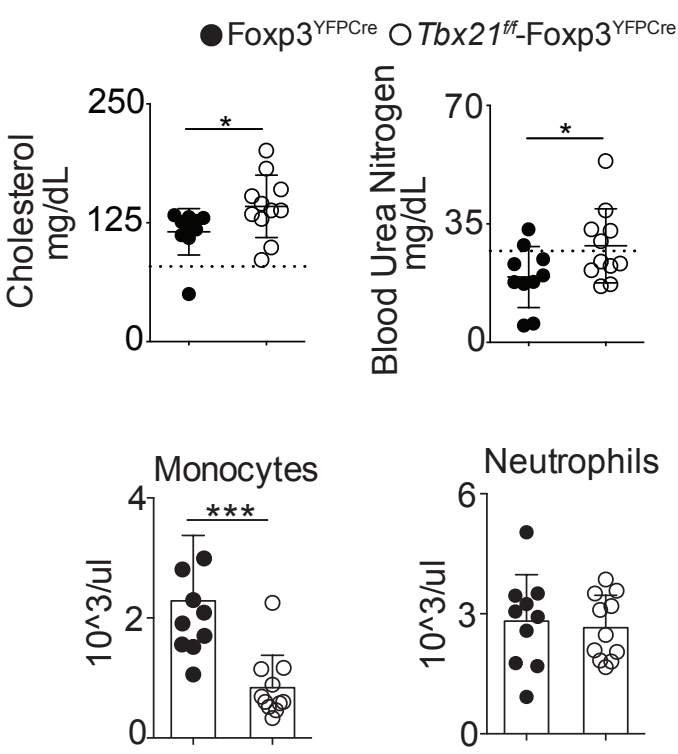

Tbx $21^{\text {fff-Foxp }} 3^{\text {YFPCre }}$

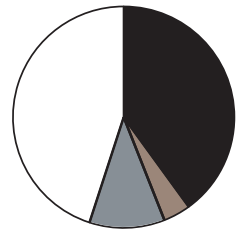

Neutrophils $40 \%$ 口Lymphocytes $4 \%$ 口Eosinophils $45 \%$ 口Monocytes $11 \%$ 
Figure 3.
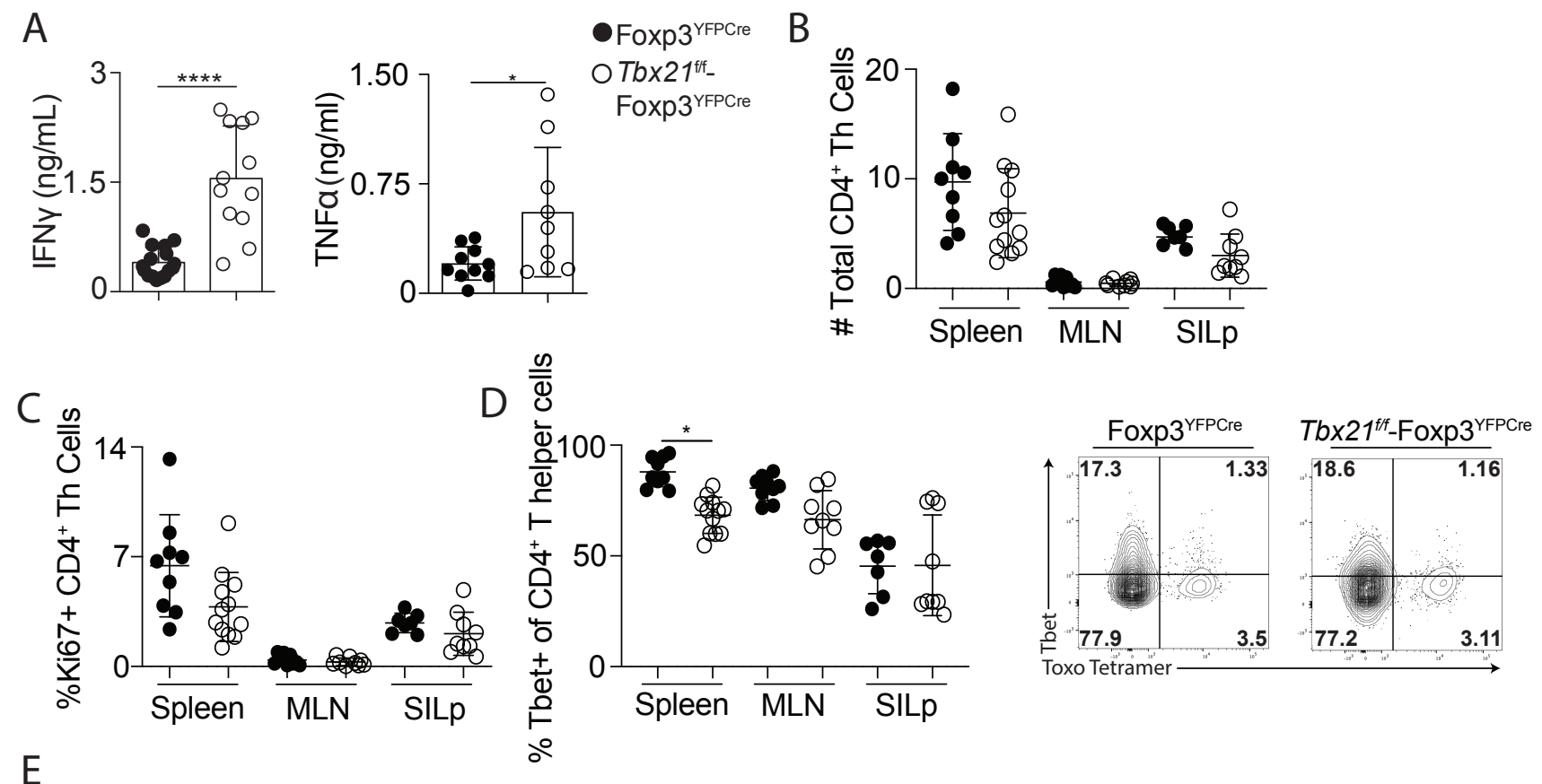

$\mathrm{E}$
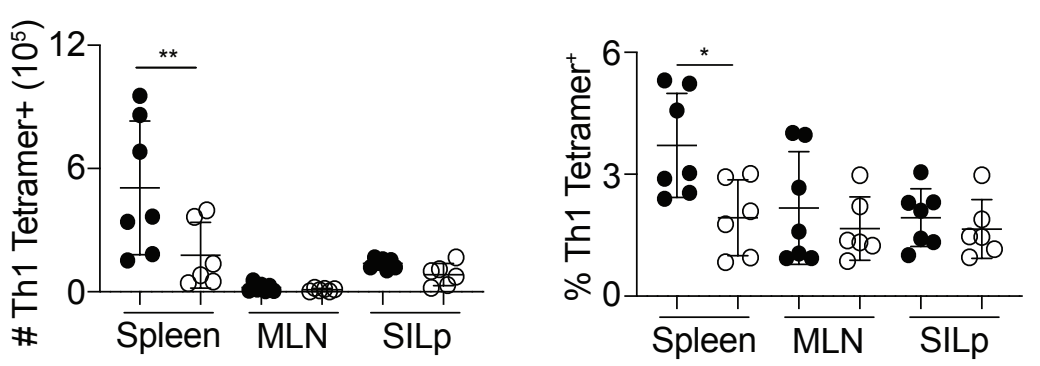
Figure 4.

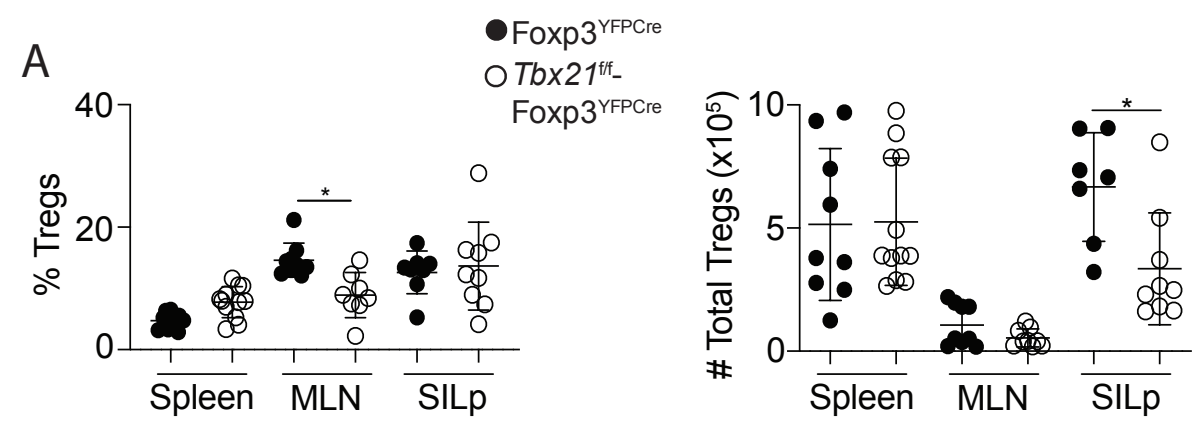

B
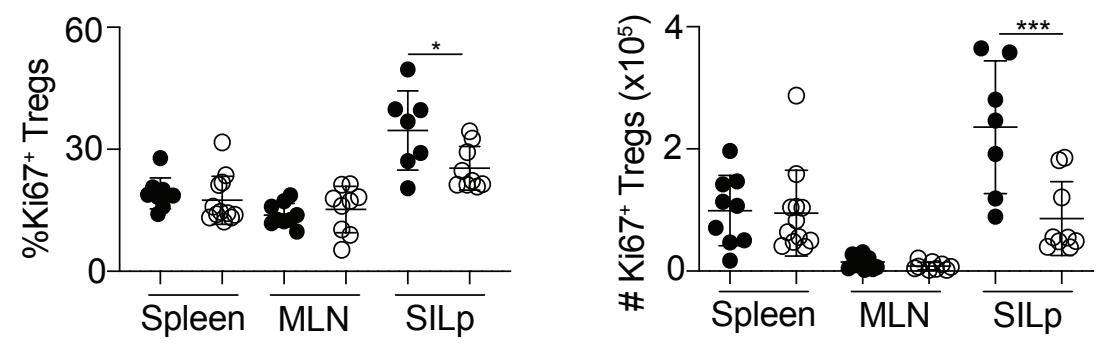

C
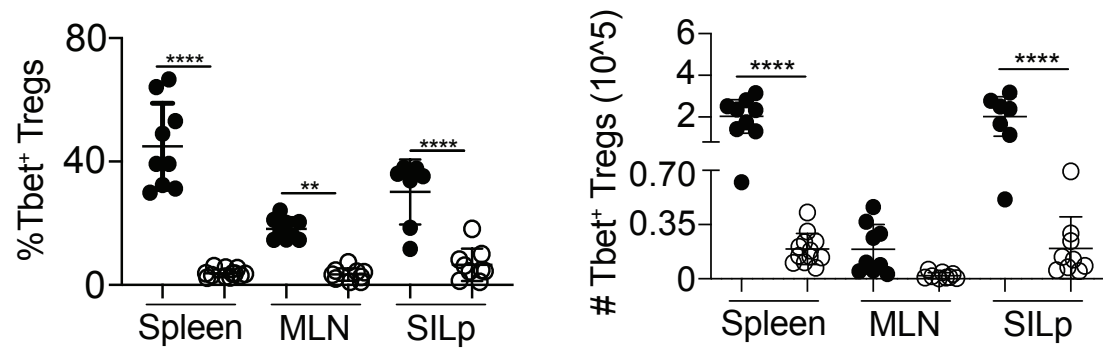
bioRxiv preprint doi: https://doi.org/10.1101/2021.09.03.458860; this version posted September 4, 2021. The copyright holder for this preprint (which was not certified by peer review) is the author/funder, who has granted bioRxiv a license to display the preprint in perpetuity. It is made available under aCC-BY-NC-ND 4.0 International license.

Figure 5.

A

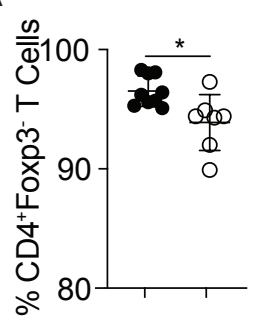

B
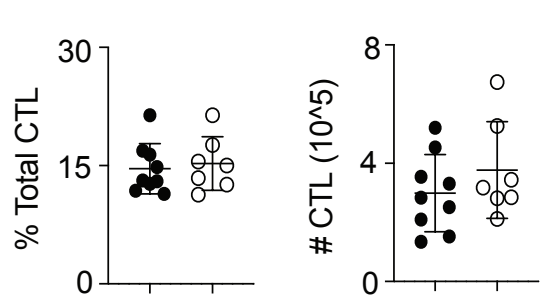

C
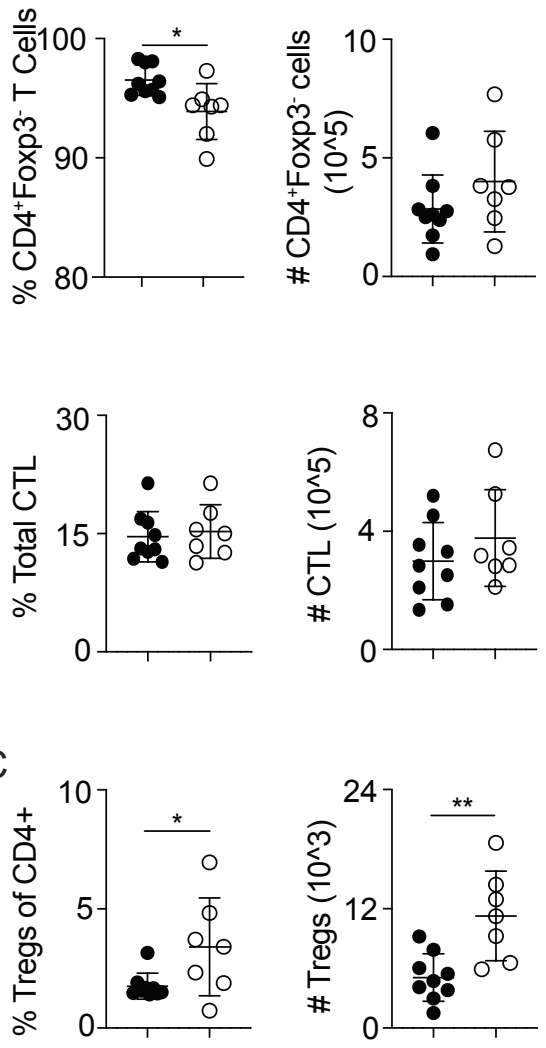
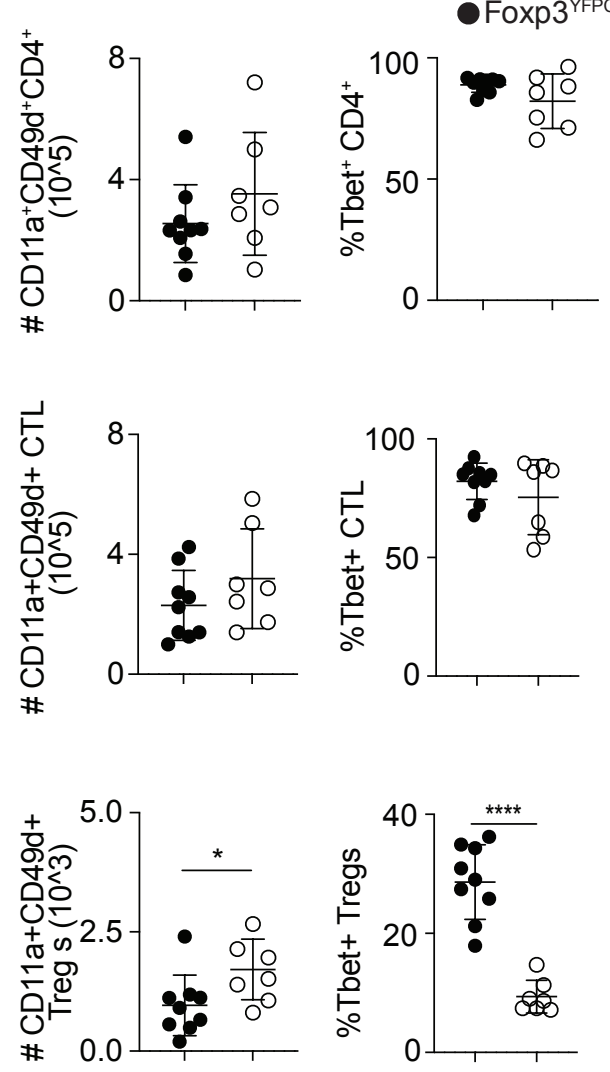
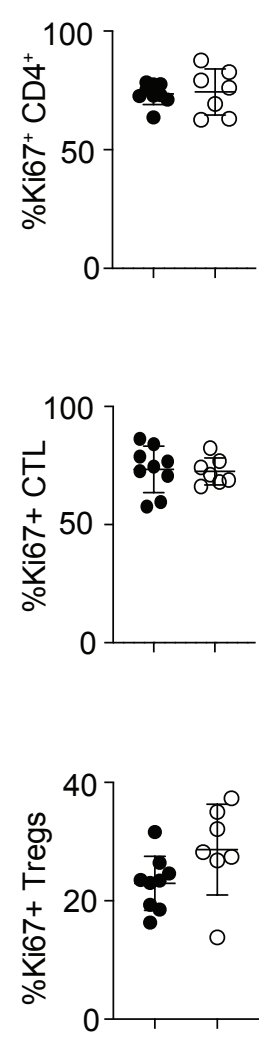


\section{Figure 6.}

A

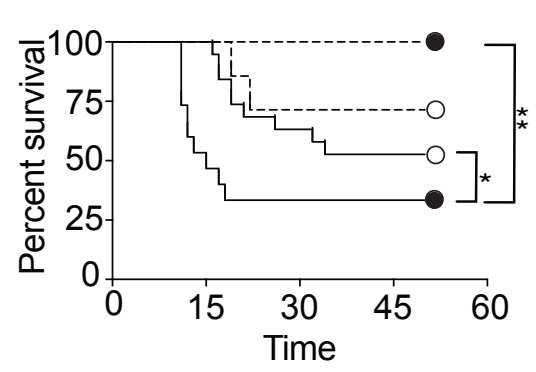

C

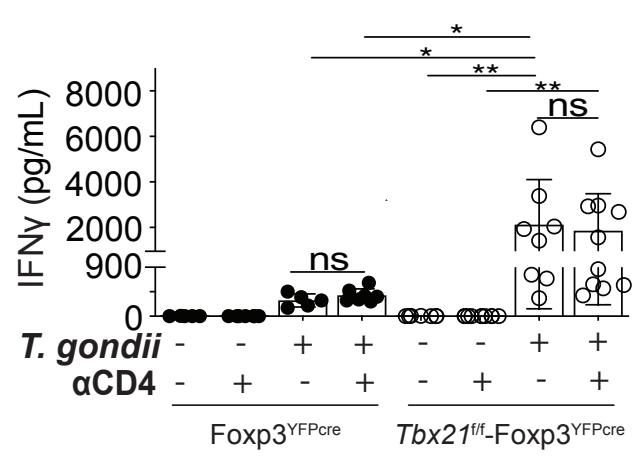

B

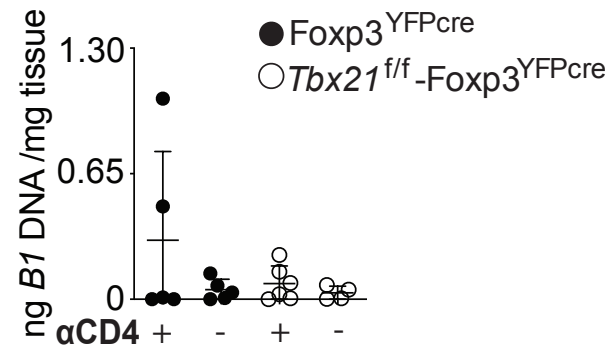




\section{Figure 7.}

A
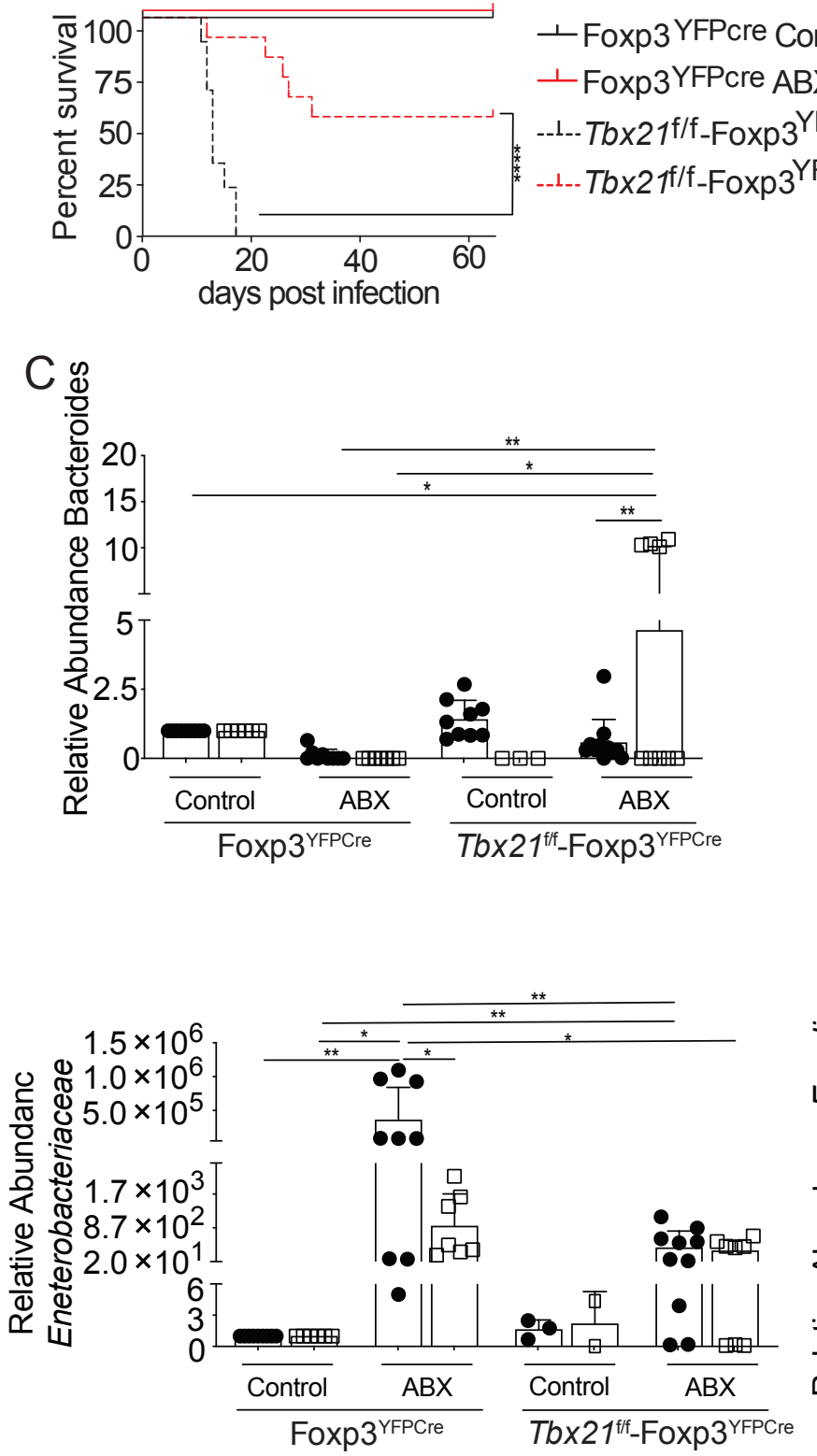

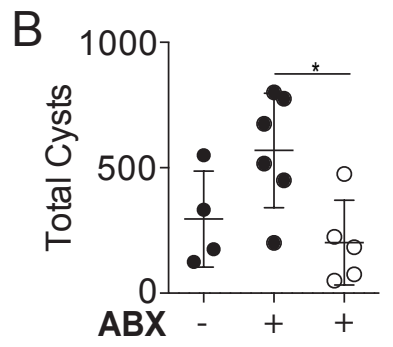

- Foxp3 $3^{\text {YFPCre }}$

O Tbx $21^{\mathrm{fff}}$-Foxp $3^{\mathrm{YFPCr}}$

-.--. Tbx21/f/f-Foxp3 YFPcre Control -..-.-Tbx2 f/f-Foxp3 ${ }^{Y F P c r e} A B X$
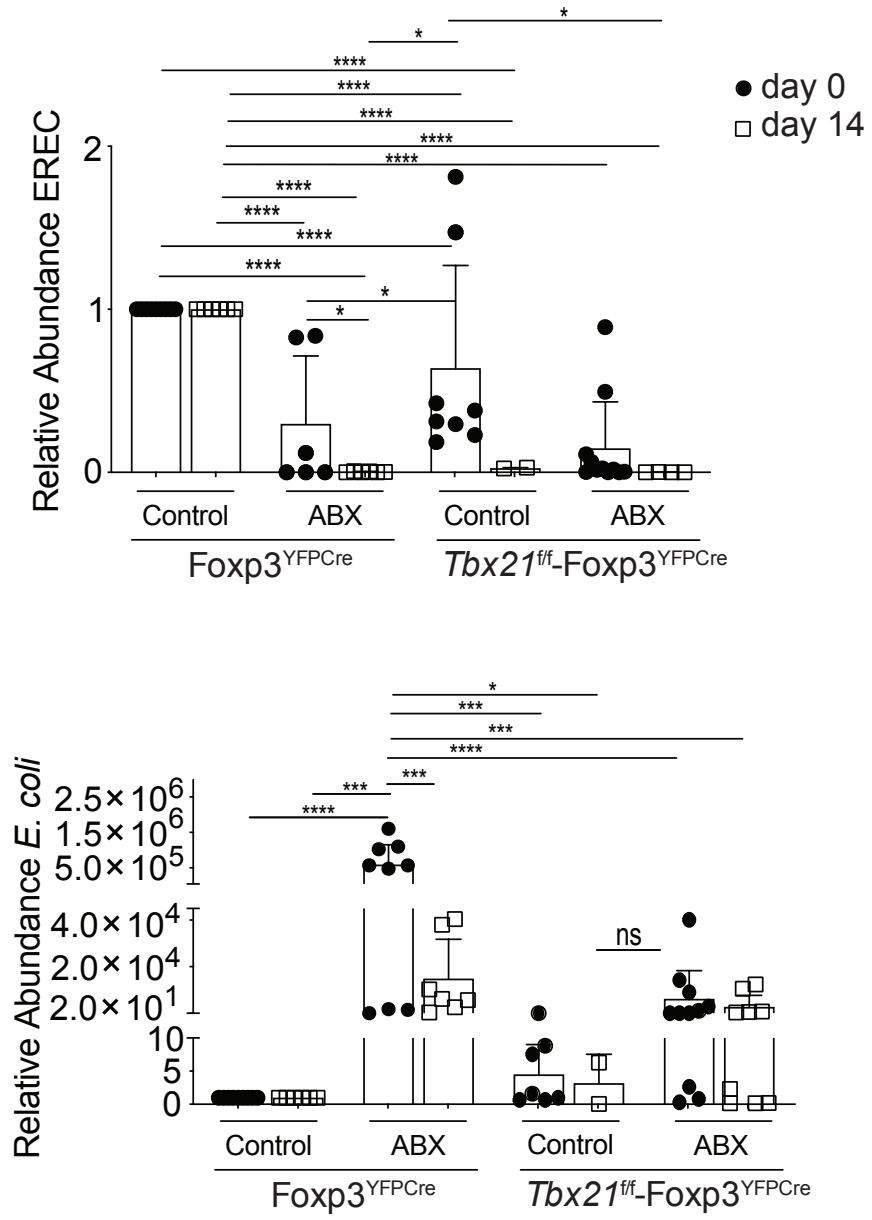
bioRxiv preprint doi: https://doi.org/10.1101/2021.09.03.458860; this version posted September 4, 2021. The copyright holder for this preprint (which was not certified by peer review) is the author/funder, who has granted bioRxiv a license to display the preprint in perpetuity. It is made available under aCC-BY-NC-ND 4.0 International license.

\section{Figure 8.}
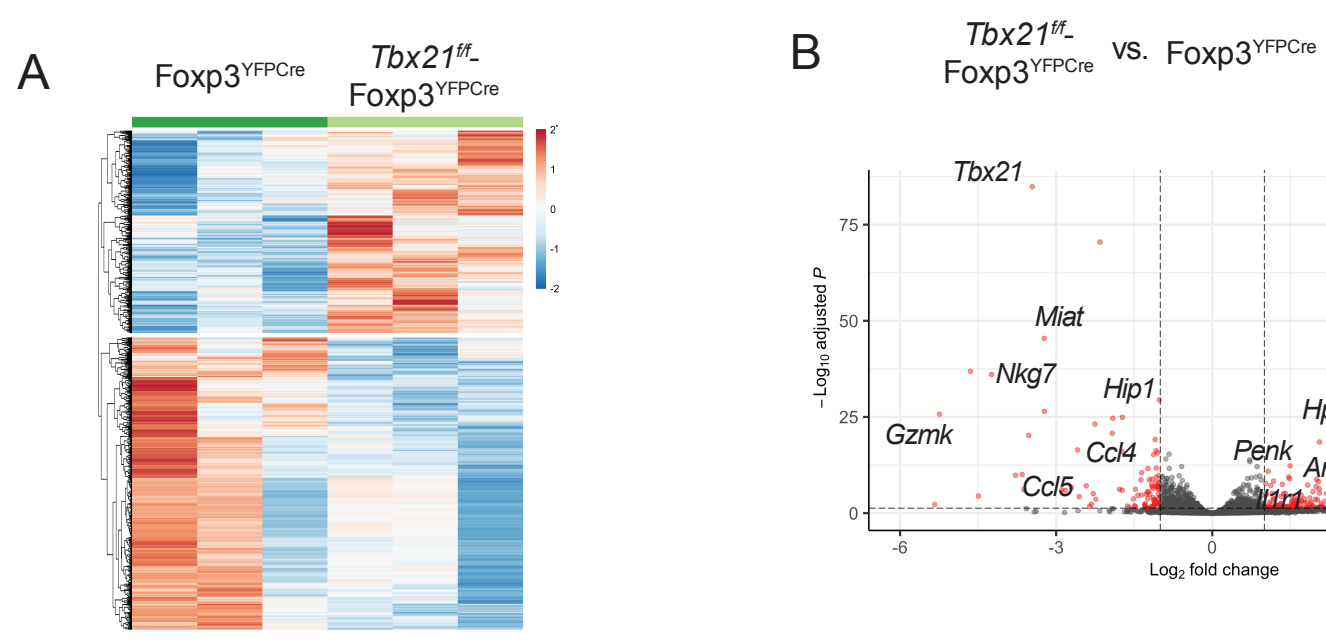

C

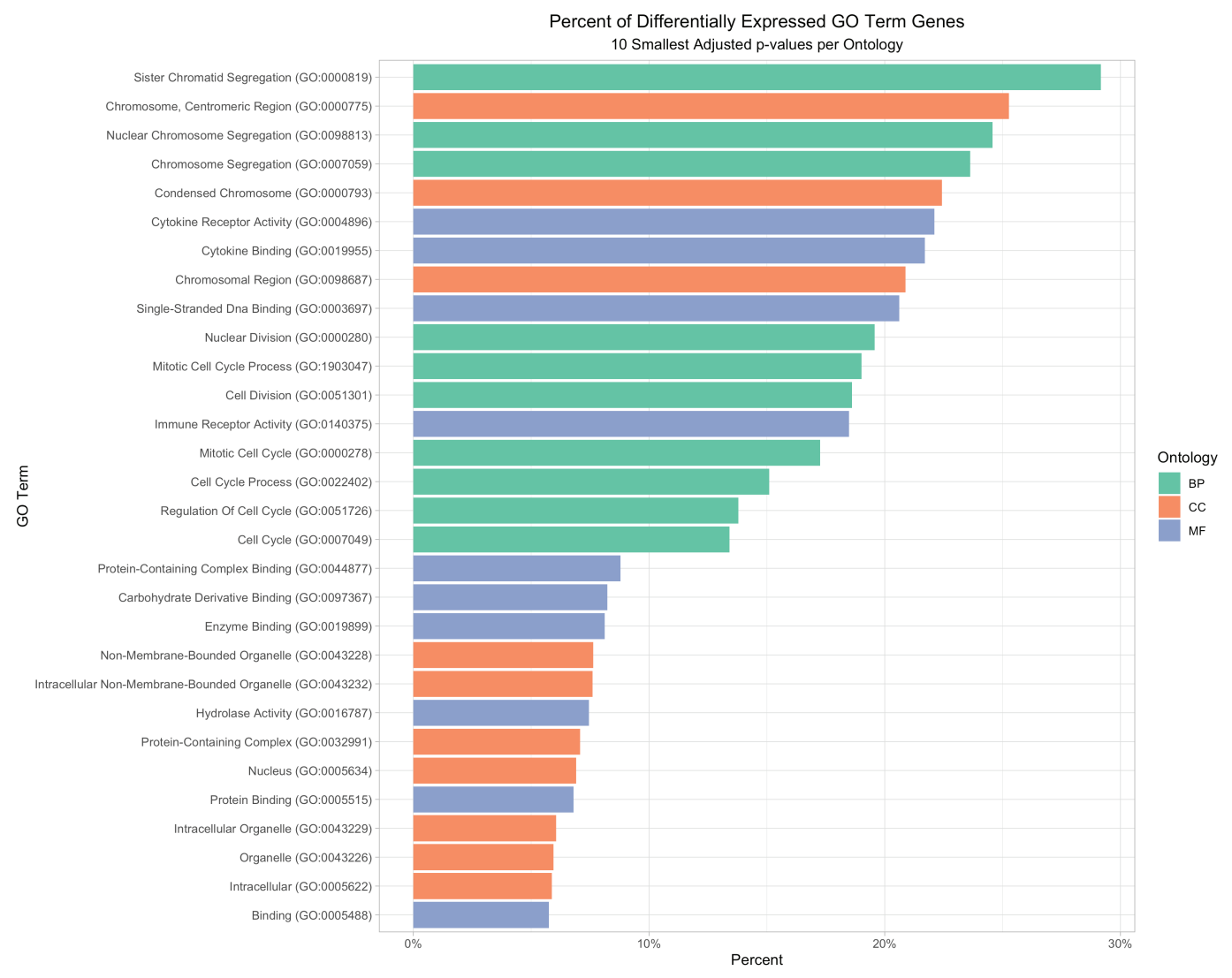

